\title{
Regulation of Escherichia coli cell envelope proteins involved in protein folding and degradation by the Cpx two-component system
}

\author{
Joe Pogliano, ${ }^{1,4}$ A. Simon Lynch, ${ }^{1,3}$ Dominique Belin, ${ }^{2}$ E.C.C. Lin, ${ }^{1}$ and Jon Beckwith ${ }^{1}$ \\ ${ }^{1}$ Department of Microbiology and Molecular Genetics, Harvard Medical School, Boston, Massachusetts 02115 USA; \\ ${ }^{2}$ Department de Pathologie, Centre Medical Universitaire, 1211 Geneva 4, Switzerland
}

We show that the two-component signal transduction system of Escherichia coli, CpxA-CpxR, controls the expression of genes encoding cell envelope proteins involved in protein folding and degradation. These findings are based on three lines of evidence. First, activation of the Cpx pathway induces 5- to 10-fold the synthesis of DsbA, required for disulfide bond formation, and DegP, a major periplasmic protease. Second, using electrophoretic mobility shift and DNase I protection assays, we have shown that phosphorylated CpxR binds to elements upstream of the transcription start sites of $d s b A, \operatorname{deg} P$, and $p p i A(\operatorname{rot} A)$, the latter coding for a peptidyl-prolyl cis/trans isomerase. Third, we have demonstrated increased in vivo transcription of all three genes, $d s b A, \operatorname{degP}$, and ppiA, when the Cpx pathway is activated. We have identified a putative CpxR consensus binding site that is found upstream of a number of other $E$. coli genes. These findings suggest a potentially extensive Cpx regulon including genes transcribed by $\sigma^{70}$ and $\sigma^{\mathrm{E}}$, which encode factors involved in protein folding as well as other cellular functions.

[Key Words: DsbA; Cpx; DegP; protein folding; transcription]

Received January 28, 1997; revised version accepted March 24, 1997.

A number of proteins have been identified in bacteria that catalyze different steps in the folding of cell envelope proteins. Periplasmic proteins catalyze disulfide bond formation, the isomerization of peptidyl-proline bonds, and protein degradation, and may be important for the assembly of outer membrane proteins (Wulfing and Pluckthun 1994). Under certain conditions, cell envelope proteins may be more exposed to environmental stresses than cytoplasmic proteins, making the need for protein maintenance and repair systems specific for the cell envelope important for survival (Visick and Clarke 1995). However, very little is known about how bacteria regulate the expression of periplasmic protein folding catalysts.

In Escherichia coli, the best understood periplasmic protein folding pathway is the Dsb system that catalyzes disulfide bond formation. The DsbA and DsbB proteins are required for the formation of disulfide bonds in cell envelope proteins (Bardwell et al. 1991, 1993; Kamitani et al. 1992; Jander et al. 1994; Guilhot et al. 1995). The

\footnotetext{
${ }^{3}$ Present address: Tularik Inc., South San Francisco, California 94080 USA.

${ }^{4}$ Corresponding author. Present address: Department of Biology, University of California, San Diego, California 92093-0322 USA.

E-MAIL jpoglian@jeeves.ucsd.edu; FAX (619) 822-1431.
}

DsbC protein is apparently also involved in cell envelope protein folding as it mediates the shuffling of disulfide bonds when incorrect disulfide bonds have formed (Rietsch et al. 1996).

In addition to proteins containing disulfide bonds, those containing proline residues may also require the activity of folding catalysts for efficient folding. Peptidyl-proline residues can occur in either the cis or trans conformations, yet usually only one conformation is suitable to yield a correctly folded protein (Wulfing and Pluckthun 1994). E. coli contains at least three periplasmic proteins catalyzing isomerization, peptidyl-prolyl cis/trans isomerases (PPIases) or rotamases, each belonging to a different family: PpiA (cyclophilin family) (Liu and Walsh 1990; Hayano et al. 1991), FkpA (FKBP family) (Roof et al. 1994; Wulfing et al. 1994; Horne and Young 1995), and SurA (PpiC family) (Rahfeld et al. 1994; Rudd et al. 1995; Lazar and Kolter 1996; Missiakas et al. 1996; Rouvière and Gross 1996). Although all of the genes encoding these enzymes are nonessential, PpiA is a potent PPIase in vitro (Liu and Walsh 1990; Hayano et al. 1991), and SurA stimulates the rate of folding of the outer membrane protein LamB in vivo (Lazar and Kolter 1996; Missiakas et al. 1996; Rouvière and Gross 1996).

If any of these periplasmic protein-folding catalysts is regulated, a mechanism (or mechanisms) must exist for 
sensing either cell envelope protein-folding defects or the conditions that lead to folding defects and for transmitting these signals across the inner membrane. A stress response pathway involved in the maturation of cell envelope proteins has been identified recently in $E$. coli. This pathway requires $\sigma^{\mathrm{E}}$, a member of the ECF (extra cytoplasmic function) family of transcription factors, as well as at least two Rse (regulator of sigma $\underline{E}$ ) proteins. $\sigma^{\mathrm{E}}$ Activity is induced by heat shock, by the overproduction of outer membrane proteins, and by sur $A$ mutations (Mecsas et al. 1993; Raina et al. 1995; Rouviere et al. 1995). Recent evidence suggests that the transmembrane protein RseA is an anti- $\sigma$ factor whose activity is regulated by the periplasmic protein RseB (De Las Peñas et al. 1997).

The $\sigma^{\mathrm{E}}$ regulon includes at least 10 genes, based on the analysis of two-dimensional gels after overproduction of $\sigma^{\mathrm{E}}$, but only three of these have been identified; $\operatorname{deg} P$, rрoH $\left\langle\sigma^{32}\right\}$, and rpoE (Raina et al. 1995; Rouviere et al. 1995). The $\operatorname{deg} P$ gene encodes a periplasmic protease induced by heat shock (Lipinska et al. 1988; Strauch and Beckwith 1988). Although the cellular substrates of DegP are not known, certain unstable foreign proteins are stabilized by $\operatorname{deg} P$ mutations (Strauch et al. 1989). The rpoH gene encodes the heat shock sigma factor, $\sigma^{32}$, which directs transcription of the genes encoding the classical heat shock response, such as the chaperones DnaK/J and GroES/EL.

In bacteria, sensing and responding to external stimuli is usually mediated by two-component signal transduction systems (for review, see Parkinson and Kofoid 1992), and one might therefore expect such a system to play a role in both detecting cell envelope defects and coordinating the appropriate response. The Cpx system, composed of the CpxA sensor kinase and the CpxR response regulator (Dong et al. 1993), represents a possible candidate for such a system. The $c p x$ locus was first identified by dominant mutations in the $c p x A$ gene that adversely affect a number of cell envelope processes, such as the ability to transport small molecules into the cell via proton-driven cotransporters, F plasmid conjugation, and the production of outer membrane proteins (for summary, see Rainwater and Silverman 1990). More recently, these so-called $c p x A^{*}$ mutations were found to confer resistance to the toxic effects associated with the expression and export of a hybrid protein (Cosma et al. 1995; Snyder et al. 1995) and lead to constitutively high expression from the degP promoter (Danese et al. 1995). Furthermore, the wild-type Cpx proteins stimulate transcription of the $\operatorname{deg} P$ gene in response to overexpression of NlpE (Danese et al. 1995), a lipoprotein of unknown function (Gupta et al. 1995). In addition to CpxA and $\mathrm{CpxR}, \sigma^{\mathrm{E}}$ is required for induction of $\operatorname{deg} P$ transcription (Danese et al. 1995).

Because $\sigma^{\mathrm{E}}$ appears to function as an extracytoplasmic periplasmic stress response pathway and $\mathrm{Cpx}$ and $\sigma^{\mathrm{E}}$ together control expression of $\operatorname{deg} P$ transcription, it has been suggested that the Cpx proteins are also part of a stress response pathway involved in monitoring periplasmic protein folding (Cosma et al. 1995). However, the relationship between $\mathrm{Cpx}$ and $\sigma^{\mathrm{E}}$ is unclear. For example, Cpx could regulate $\operatorname{deg} P$ expression indirectly by altering the activity or expression of the proposed regulators of $\sigma^{\mathrm{E}}$, namely RseAB. Alternatively, Cpx could directly activate $\sigma^{\mathrm{E}}$-transcribed genes by binding to sequences adjacent to $\sigma^{\mathrm{E}}$-dependent promoters. Finally, Cpx could play a more general role in cell physiology by controlling the transcription of genes transcribed by other sigma factors, such as $\sigma^{70}$, in addition to $\sigma^{\mathrm{E}}$. Here, we identify new targets of the Cpx signal transduction pathway and provide evidence that CpxA and CpxR serve to directly regulate the expression of genes encoding periplasmic protein-folding catalysts. We also demonstrate that phosphorylated CpxR binds to specific sequences upstream of both $\sigma^{\mathrm{E}}$ and $\sigma^{70}$ promoters, allowing the identification of a putative DNA-binding consensus sequence and suggesting that CpxA and CpxR comprise an extracellular stress response that possibly controls the expression of a large number of genes in E. coli.

\section{Results}

Temperature-regulated expression of $\operatorname{Deg} P$ in $\mathrm{cpx}^{+}$, $\Delta \mathrm{cpx}$, and $\mathrm{cpxA}^{*}$ mutants

Dominant, gain-of-function $c p x A^{\star}$ mutations that result in pleiotropic phenotypes have been suggested to lock the CpxA protein into a conformation that results in constitutive signaling in the absence of the normal stimulus or ligand. Consistent with this idea, $c p \times A^{\star}$ mutations lead to constitutive, high-level expression of the heat-inducible $\operatorname{deg} P$ gene (Danese et al. 1995). Expression of DegP is greatly increased in mutants containing $c p \times A^{*}$ mutations (Fig. 1). Because both temperature and Cpx appear to regulate the expression of DegP, we examined the Cpx dependence of the effect of temperature on the expression of DegP (Fig. 1). The rates of synthesis of the DegP protein in a variety of $c p x$ mutants at $30^{\circ} \mathrm{C}$, $37^{\circ} \mathrm{C}$, or after a 10 -min shift from $30^{\circ} \mathrm{C}$ to $42^{\circ} \mathrm{C}$ were measured in pulse-chase immunoprecipitation experiments, and the quantitated results are shown in Figure 1. In wild-type cultures, synthesis of DegP is slightly elevated $(-50 \%)$ when grown at $37^{\circ} \mathrm{C}$ compared with $30^{\circ} \mathrm{C}$, and DegP is induced eightfold after $10 \mathrm{~min}$ of heat shock. In $c p x A^{\star}$ mutants, rates of DegP synthesis are significantly elevated at $37^{\circ} \mathrm{C}$ compared with wild type and increase even further after a shift to $42^{\circ} \mathrm{C}$. The degree of regulation of DegP synthesis by temperature in a $c p x$ null mutant is identical to that seen with regulation in $c p x^{+}$strains. Hence, the pathway leading to activation of $\sigma^{\mathrm{E}}$ by temperature appears to be independent of Cpx.

\section{$D s b A$ is overexpressed in mutants containing $\mathrm{cpxA}^{*}$ mutations}

On the basis of experiments showing that $c p x A^{*}$ mutants constitutively express the DegP protease, we reasoned that CpxA may be a sensor of cell envelope defects and that other genes involved in maturation of cell envelope proteins may therefore be regulated by Cpx. One prediction of this model is that periplasmic protein-fold- 


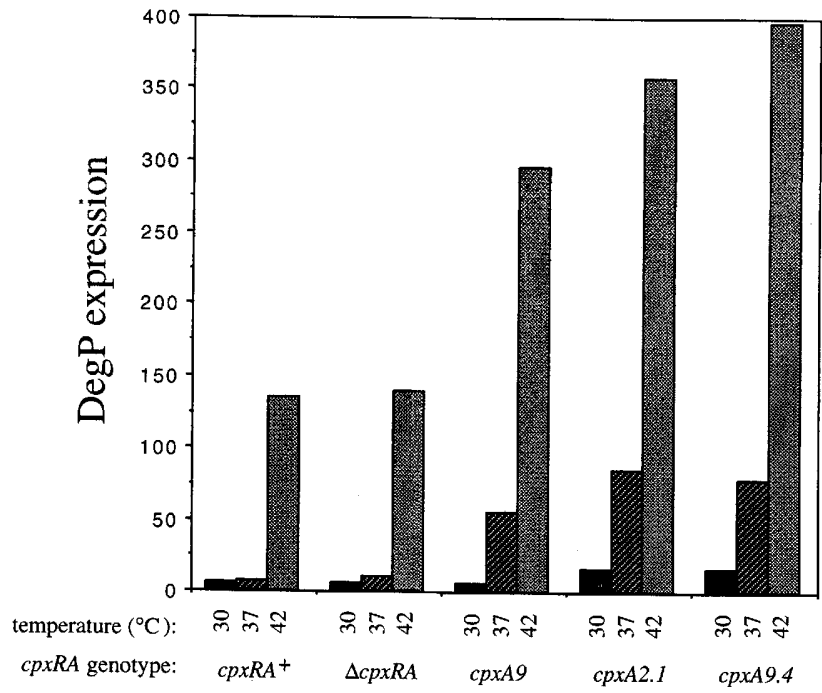

Figure 1. DegP expression in $c p x^{+}, \Delta c p x$, and $c p x A^{\star}$ mutants. Pulse-chase experiments were performed at $30^{\circ} \mathrm{C}$ (solid bars), $37^{\circ} \mathrm{C}$ (hatched bars), or after a 10 -min shift from $30^{\circ} \mathrm{C}$ to $42^{\circ} \mathrm{C}$ (shaded bars) as described in Materials and Methods. Strains are JP406 $\left(c p x R A^{+}\right)$, ECL1212 ( (cpxA2.1), and JP468 (cpxA9.4). The data shown is from a single, representative experiment. Results using another $c p x^{+}$wildtype strain (JP466) were similar.

ing catalysts will be expressed at higher levels in strains containing $c p \times A^{\star}$ mutations. To test this idea, we examined the expression levels of DsbA and SurA, two proteins important for folding of cell envelope proteins (Bardwell et al. 1991; Lazar and Kolter 1996). The rates of synthesis of the DsbA and SurA proteins were measured in $c p \times A^{*}$ mutants using pulse-chase immunoprecipitation experiments. Expression of the SurA protein was not elevated in $c p x A^{*}$ mutants (data not shown); however, expression of DsbA was greatly affected. As is shown in Figure 2a, DsbA was increased four- to eightfold by $c p x A^{\star}$ mutations in strains grown at $37^{\circ} \mathrm{C}$, a level of induction comparable to that seen for DegP in the same experiments (Fig. 2b).

\section{$D s b A$ is regulated by the wild-type Cpx signal transduction pathway}

In addition to being regulated by $c p x A^{\star}$ mutations, the $\operatorname{deg} P$ gene is regulated by the wild-type Cpx proteins in response to overproduction of an exported lipoprotein, NlpE (Danese et al. 1995). We examined the ability of $\mathrm{NlpE}$ overexpression to induce synthesis of the DsbA and $\operatorname{Deg} P$ proteins using pulse-chase immunoprecipitation experiments. A plasmid, pND18, expressing NlpE from the arabinose promoter, induces the DegP protein $\sim 10$-fold (Fig. 2b). Furthermore, the induction of DegP protein by NlpE was found to be dependent on the Cpx proteins. These results are in accord with those of previous studies based on strains containing a $\lambda$ phage expressing a $\operatorname{deg} P-l a c Z$ transcriptional fusion, suggesting that both methods accurately reflect changes in tran- scription from the $\operatorname{deg} P$ promoter in vivo. The rates of synthesis of DsbA were increased approximately fourfold after $1.25 \mathrm{hr}$ of production of NlpE (Fig. 2a). Overproduction of NlpE did not result in DsbA induction if the $c p x$ operon was deleted. These results suggest that expression of DsbA is regulated by the Cpx pathway.

\section{Cpx regulates transcription of the $\mathrm{dsbA}$ gene}

The $d s b A$ gene is transcribed from two promoters: a proximal promoter (P1) immediately upstream of the $d s b A$ open reading frame and a distal promoter $(\mathbf{P} 2)$ up-
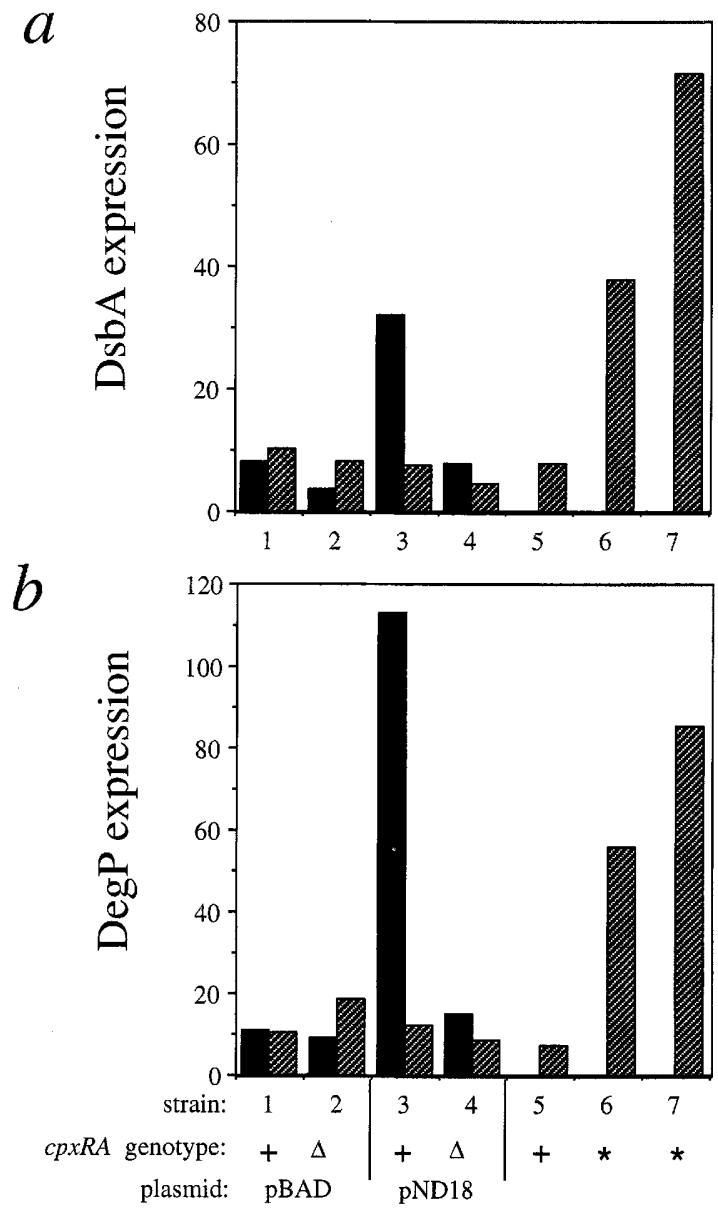

Figure 2. DegP and DsbA expression in $c p x A^{\star}$ mutants or in $c p x^{+}$and $\Delta c p x$ null strains when NlpE is expressed from a highcopy-number plasmid. The genotype of each strain is indicated as + for $c p x^{+}, \Delta$ for $\Delta c p x$, and * for $c p x A^{\star}$. Strains 1-4 contain the plasmid pND18 or pBAD22 and were grown with (solid bars) or without (hatched bars) arabinose. Strains 5, 6, and 7 do not contain plasmids and were not grown in the presence of arabinose. Cultures grown at $37^{\circ} \mathrm{C}$ in minimal maltose medium were either induced (solid bars) or not induced (hatched bars) with $0.2 \%$ arabinose for $1.25 \mathrm{hr}$ and then pulse-labeled as described in Materials and Methods. Strain 1 (JP472); strain 2 (JP474); strain 3 (JP558); strain 4 (JP560); strain 5 (JP406); strain 6 (JP408); strain 7 (JP467). The results shown are from a typical experiment. Similar results were obtained using a different time of induction of NlpE with arabinose ( $1.5 \mathrm{hr}$ ) or using a different strain background in which cells cannot catabolize arabinose (JP313). 
stream of an open reading frame (yihE) that precedes the $d s b A$ gene (Belin and Boquet 1994). The DsbA protein might be regulated by Cpx directly by stimulating transcription of one or both of the $d s b A$ promoters or indirectly by another mechanism. We therefore quantitated the in vivo levels of RNA transcripts originating from both promoters (P1 and $\mathrm{P} 2)$ by RNase protection. RNA was harvested from $c p x^{+}$- or $\Delta c p x$-mutant strains containing either a control plasmid, pBAD22, or a plasmid that overexpresses NlpE, pND18. Expression of the distal promoter $(\mathrm{P} 2)$ is induced 10 -fold by NlpE overproduction, whereas the proximal promoter $(\mathrm{P} 1)$ is not induced (Fig. 3a). Induction of $\mathrm{P} 2$ was not observed in strains containing a $c p x$ null mutation (Fig. 3a).

We then investigated the effect that various mutations in the $c p x$ locus have on expression from P2. The amount of RNA produced from the P2 promoter was assayed by RNase protection in strains containing either the wild-type $c p_{x}$ operon, the defined $c p_{x} R A$ deletion, or one of two $c p x A^{\star}$ mutations. As is shown in Figure $4 \mathrm{a}$, strains containing $c p x A^{\star}$ mutations produced from fourto sevenfold more of the transcript originating from P2 relative to the amount produced in the $c p x^{+}$parent strain. This difference is highly significant, as determined by standard $t$-test analysis.

\section{Kinetics of activation of the Cpx pathway by N1pE overproduction}

$\mathrm{NlpE}$ overproduction is routinely used as an activator of the Cpx pathway, but the mechanism underlying such activation is unknown. To gain further insight into the phenomenon, we determined the kinetics of activation of the Cpx pathway following induction of NlpE synthesis. A rapid activation of $\mathrm{Cpx}$ may reflect a more direct role for NlpE in activating the Cpx pathway. However, if the kinetics of activation of Cpx were found to be slow and the strength of the signal to increase with time of synthesis, NlpE overproduction may result in an indirect effect on cell envelope structure. NlpE synthesis was induced by the addition of arabinose to exponentially growing cultures, and the expression from the $d s b A$ P2 promoter was measured at various times by RNase protection. The $d s b A \mathrm{P} 2$ transcript is rapidly and maximally induced within 5 min of induction of NlpE (Fig. 5). Overproduction of another exported protein, alkaline phosphatase (AP), did not significantly induce $d s b A$ transcription, despite the fact that AP was more highly expressed than NlpE in these experiments, as revealed by Coomassie staining of total proteins at the end of the experiment (data not shown). These results are consistent with those of Danese et al. (1995) in which the overproduction of several other exported proteins did not stimulate the Cpx response and suggest that $\mathrm{NlpE}$ is a specific and potent activator of the Cpx pathway.

Binding of $\mathrm{His}_{6}-\mathrm{Cpx} \mathrm{R}$ and $\mathrm{His}_{6}-\mathrm{Cpx} \mathrm{R}-\mathrm{P}$ proteins to the transcriptional regulatory region of the $\operatorname{deg} \mathrm{P}$ gene

To determine whether the CpxR protein, or more likely the phosphorylated form (CpxR-P), serves directly as a
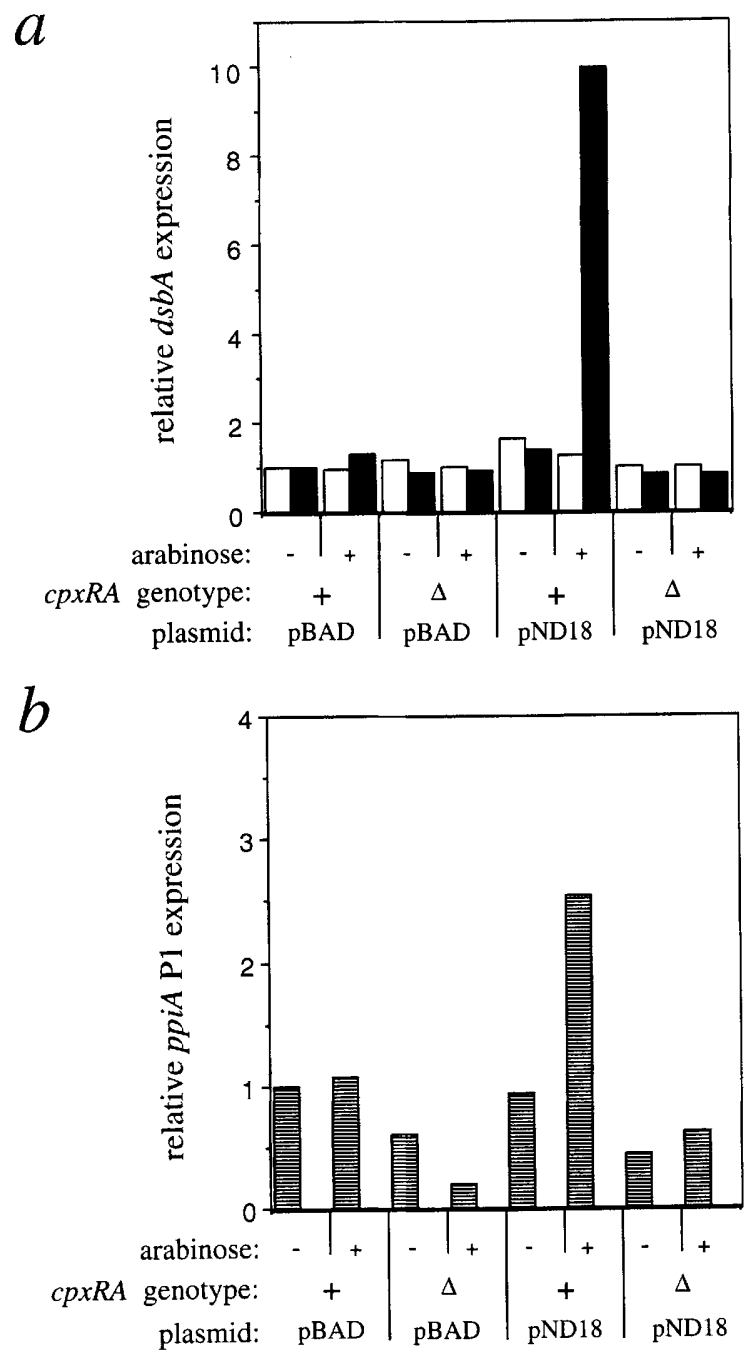

Figure 3. Expression of $d s b A$ and ppiA RNA in strains in which the Cpx pathway has been activated by NlpE overproduction. Transcription from the dsbA P1 (a, open bars) and P2 $(a$, solid bars) promoters, and the ppiA P1 promoter $(b)$ was measured by RNase protection. Strains contain the plasmids pND18 or pBAD22 and were grown at $37^{\circ} \mathrm{C}$ in minimal maltose medium and then either induced $(+)$ or not induced $(-)$ with $0.2 \%$ arabinose for $1.5 \mathrm{hr}$. The strains used were JP472 $\left(c p x^{+}\right)$ pBAD22), JP474 ( $\Delta c p x /$ pBAD22), JP558 $\left(c p x^{+} / \mathrm{pND} 18\right)$, and JP560 ( $\Delta c p x / \mathrm{pND} 18)$. The results are expressed relative to the values obtained for JP472 and grown in the absence of arabinose.

transcriptional regulator of the $\operatorname{deg} P$ locus, we tested whether binding of the CpxR protein to DNA fragments containing the transcriptional regulatory region of the $\operatorname{deg} P$ gene could be detected. For this study, a derivative of the CpxR protein $\left(\mathrm{His}_{6}-\mathrm{CpxR}\right)$ bearing an amino-terminal, oligohistidine extension was used prior to or after incubation with acetyl phosphate.

In a preliminary search for specific DNA-binding sites for the $\mathrm{His}_{6}-\mathrm{CpxR}$ and $\mathrm{His}_{6}-\mathrm{CpxR}-\mathrm{P}$ proteins, electrophoretic mobility shift (EMS) and DNase I footprinting assays were performed using a 362-bp fragment (derived from pBTKSdegP1) that includes $301 \mathrm{bp}$ of the region 


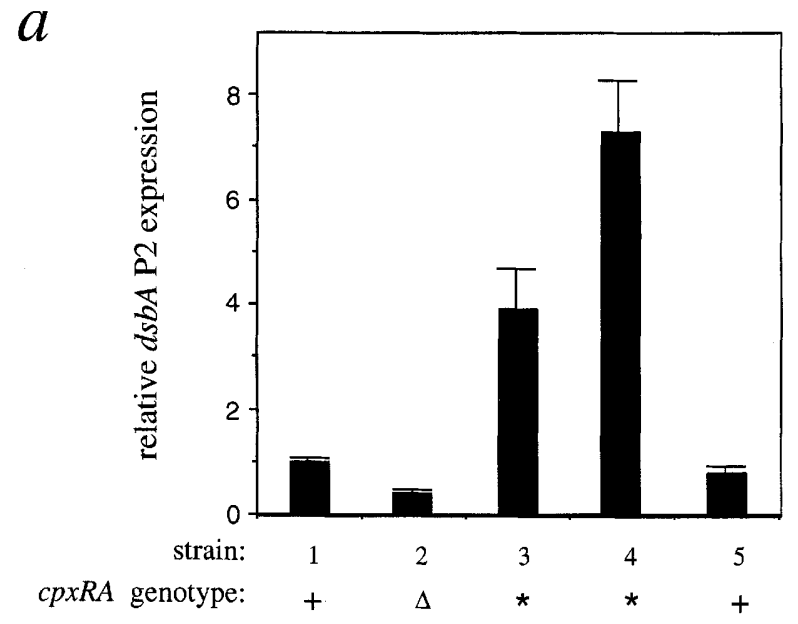

$b$

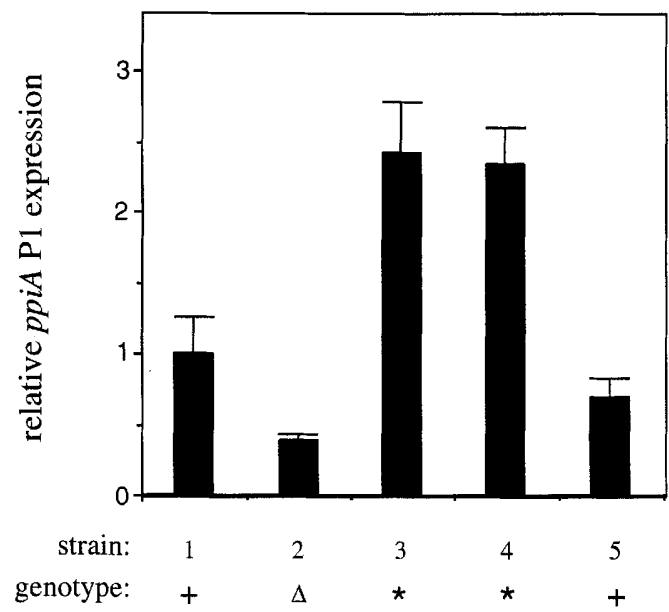

Figure 4. Expression from the yihE-dsbA P2 promoter and the ppiA $\mathrm{P} 1$ promoter in $c p x$ mutants. Three independent cultures of each strain were grown to an $\mathrm{OD}_{600}$ of $\sim 0.3$. Samples were then taken, and expression of mRNA from each promoter was assayed by RNase protection. The average value for each strain (labeled 1-5) and the S.D. (error bars) for that average are expressed relative to the values obtained for strain 1 . Results for the yihE-dsbA P2 promoter are shown in $a$ (top) and those for the ppiA P1 promoter are shown in $b$ (bottom). Strain 1 (JP406); strain 2 (ECL1212); strain 3 (JP408); strain 4 (JP467); strain 5 (JP466).

upstream of the initiation codon of DegP. The results obtained were indicative of the presence of two distinct and well-separated binding sites, at which the phosphorylated form of the protein appeared to bind with a significantly higher affinity (data not shown).

Figure 6a shows DNase I footprinting analysis of the binding of the $\mathrm{His}_{6}-\mathrm{CpxR}$ and $\mathrm{His}_{6}-\mathrm{CpxR}-\mathrm{P}$ proteins to a 249-bp fragment (derived from pBTKSdegP2) that includes the $\sigma^{\mathrm{E}}$ promoter of the $\operatorname{deg} P$ gene and that contains the stronger of the two binding sites identified in the preliminary analysis. Clear DNase I footprints are only readily apparent with the $\mathrm{His}_{6}-\mathrm{CpxR}$ protein at the highest concentration of protein employed $1720 \mathrm{~nm}$; lanes 12,24). In contrast, clear DNase I footprints are observed with the $\mathrm{His}_{6}-\mathrm{CpxR}-\mathrm{P}$ protein at a significantly lower concentration (180 nM; lanes 4,16). As the concentration of the $\mathrm{His}_{6}-\mathrm{CpxR}-\mathrm{P}$ protein is increased further, the regions of protection from DNase I cleavage expand in a unidirectional fashion to include sequences located downstream of the promoter.

Figure $6 \mathrm{~b}$ shows a similar analysis of protein binding to a 213-bp fragment containing the weaker $\mathrm{His}_{6}-\mathrm{CpxR}$ $\mathrm{P}$-binding site, which is located upstream of the $\sigma^{\mathrm{E}}$ promoter-proximal site described above. In this case, DNase I footprints are not apparent with the $\mathrm{His}_{6}-\mathrm{CpxR}$ protein even at the highest concentration of protein employed $(720 \mathrm{~nm}$; lanes 9,18$)$. In contrast, clear DNase I footprints are observed on both strands of the template with the $\mathrm{His}_{6}-\mathrm{CpxR}-\mathrm{P}$ protein at a concentration of 360 nм (lanes 3,12).

The core $\mathrm{His}_{6}-\mathrm{CpxR}-\mathrm{P}$ footprints at both sites are indicated in Figure 6c (labeled as "CpxR-P binding site $\mathrm{I}^{\text {" }}$ or "CpxR-P binding site II"). Each site corresponds to the sequences at which DNase I cleavage is most significantly affected by $\mathrm{His}_{6}-\mathrm{CpxR}-\mathrm{P}$ protein binding (i.e., when $\mathrm{His}_{6}-\mathrm{CpxR}-\mathrm{P}$ is present at only relatively low concentrations).

Binding of $\mathrm{His}_{6}-\mathrm{CpxR}$ and $\mathrm{His}_{6}-\mathrm{CpxR}-\mathrm{P}$ proteins to the transcriptional regulatory region of the yihE-dsbA operon

Preliminary studies suggested that the CpxR protein binds in a phosphorylation-stimulated manner to a

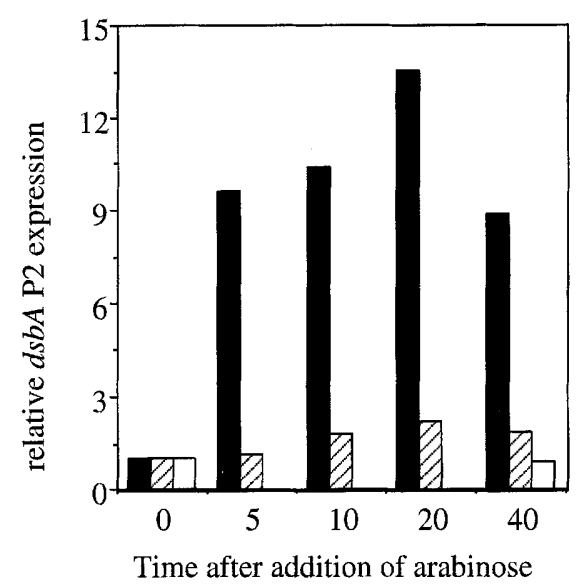

Figure 5. Kinetics of induction of the yihE-dsbA operon by NlpE. Strains containing the plasmids pND18 /solid bars; overexpresses NlpE), pDB3 (hatched bars; overexpresses AP), or pBAD22 (open bars; control plasmid) were grown aerobically in minimal maltose medium with ampicillin at $37^{\circ} \mathrm{C}$. At time zero (corresponding to an $\mathrm{OD}_{600}$ of $\sim 0.2$ ), a sample from each culture was taken and then arabinose added to a final concentration of $0.2 \%$. Samples were taken at 5,10,20, and $40 \mathrm{~min}$ after the addition of arabinose. mRNA originating from the $\mathrm{P} 2$ promoter of the $y i h E-d s b A$ operon was quantitated by RNase protection. The results are expressed relative to the values obtained for each culture at time zero. The strains were JP444 $\left(\mathrm{cpx}^{+} / \mathrm{pDB} 3\right), \mathrm{JP} 445$ $\left(\mathrm{cpx}^{+} / \mathrm{pBAD} 22\right)$, and JP446 (cp⿰ $\left.\mathrm{p}^{+} / \mathrm{pND} 18\right)$. Similar results were obtained using the ara $^{+}$strains JP472 and JP558. 
Figure 6. CpxR-P binding at sites located in the region upstream of the $\operatorname{deg} P$ gene. (a) DNase I protection assays of the binding of $\mathrm{His}_{6}-\mathrm{CpxR}$ and $\mathrm{His}_{6}-\mathrm{CpxR}-\mathrm{P}$ to $\operatorname{deg} P$ site I. A 249-bp DNA fragment jobtained by PCR amplification of the degP promoter region of pBTKSdegP2 with primers DEGP3 and DEGP2) was end-labeled with ${ }^{32} \mathrm{P}$ at its $5^{\prime}$ termini by treatment with $\mathrm{T} 4$ polynucleotide kinase, and uniquely labeled substrates were generated by EcoRI (lanes 1-12) or BamHI (lanes 13-24) digestion. The substrate DNA was present at $\sim 2 \mathrm{nM}$ in reactions that also contained no added protein (lanes 1,7,13,19), $36 \mathrm{nM} \mathrm{His}_{6}-$ CpxR-P (lanes 2,14), $90 \mathrm{~nm}$ $\mathrm{His}_{6}-$ CpxR-P (lanes 3,15), $180 \mathrm{nM} \mathrm{His}_{6}$ CpxR-P (lanes 4,16), 360 nM His $_{6}$-CpxR-P (lanes 5,17), $720 \mathrm{nM} \mathrm{His}{ }_{6}-\mathrm{CpxR}-\mathrm{P}$ (lanes 6,18), $36 \mathrm{~nm} \mathrm{His}_{6}-\mathrm{CpxR}$ (lanes 8,20), $90 \mathrm{~nm}$ $\mathrm{His}_{6}-\mathrm{CpxR}$ (lanes 9,21), $180 \mathrm{nM} \mathrm{His}_{\sigma^{-}}$ CpxR (lanes 10,22), $360 \mathrm{nM} \mathrm{His}_{6}-\mathrm{CpxR}$ (lanes 11,23), or $720 \mathrm{~nm} \mathrm{His}{ }_{6}$-CpxR (lanes $12,24)$. The sequencing ladders were generated by extension of ${ }^{32} \mathrm{P}$-end-labeled DEGP3 primer for the coding strand or DEGP2 primer for the noncoding strand using $\mathrm{pBTKSdegP} 2$ as a template. The core $\mathrm{His}_{6}$ - CpxR-P binding site $\mathrm{I}$ is indicated by the thick line; the thin line indicates the limits of the sequence shown in the lower half of $c$. $\langle b\rangle$ DNase I protection assays of the binding of $\mathrm{His}_{6}-\mathrm{CpxR}$ and $\mathrm{His}_{6}$ CpxR-P to $\operatorname{deg} P$ site II. A 213-bp DNA fragment (obtained by amplification of the $\operatorname{deg} P$ promoter region of $\mathrm{pBTKSdegP} 3$ with primers DEGP4 and DEGP5) was end-labeled with ${ }^{32} \mathrm{P}$, and uniquely labeled substrates were generated by EcoRI (lanes 1-9) or BamHI (lanes 10-18) digestion. The substrate DNA was present at $\sim 2 \mathrm{nM}$ in reactions that also contained no added protein (lanes 5,14), $90 \mathrm{nM} \mathrm{His}_{6}$-CpxR-P (lanes 1,10), $180 \mathrm{~nm} \mathrm{His}{ }_{6}-\mathrm{CpxR}-\mathrm{P}$ (lanes 2,11), $360 \mathrm{nM} \mathrm{His}_{6}$-CpxR-P (lanes 3,12), $720 \mathrm{nM} \mathrm{His}_{6}$-CpxR-P (lanes 4,13), $90 \mathrm{nM}$ $\mathrm{His}_{6}-\mathrm{CpxR}$ (lanes 6,15), $180 \mathrm{nM} \mathrm{His}{ }_{6}$ CpxR (lanes 7,16), $360 \mathrm{nM} \mathrm{His}_{6}-\mathrm{CpxR}$ (lanes 8,17), or $720 \mathrm{~nm} \mathrm{His}{ }_{6}-$ CpxR (lanes $9,18)$. Sequencing ladders were generated by extension of ${ }^{32} \mathrm{P}$-end-labeled DEGP4 primer for the coding strand or DEGP5 primer for the noncoding strand using pBTKSdegP3 as a template. The core $\mathrm{His}_{6}-$ CpxR-P binding site II is indicated by the thick line; the thin line indicates the limits of the sequence shown in the upper half of $c$. $(c)$ The location of CpxR-P binding sites in the region upstream of the $\operatorname{deg} P$ gene. Elements of the $\sigma^{\mathrm{E}}$ promoter (Erickson and Gross 1989) are indicated. The core CpxR-P binding sites I and II, as defined by the patterns of altered DNase I reactivity observed on both strands in the presence of a limiting concentration of $\mathrm{His}_{6}-\mathrm{CpxR}-\mathrm{P}$, are indicated by the brackets.

\section{a $\operatorname{deg} P$ site I coding strand}

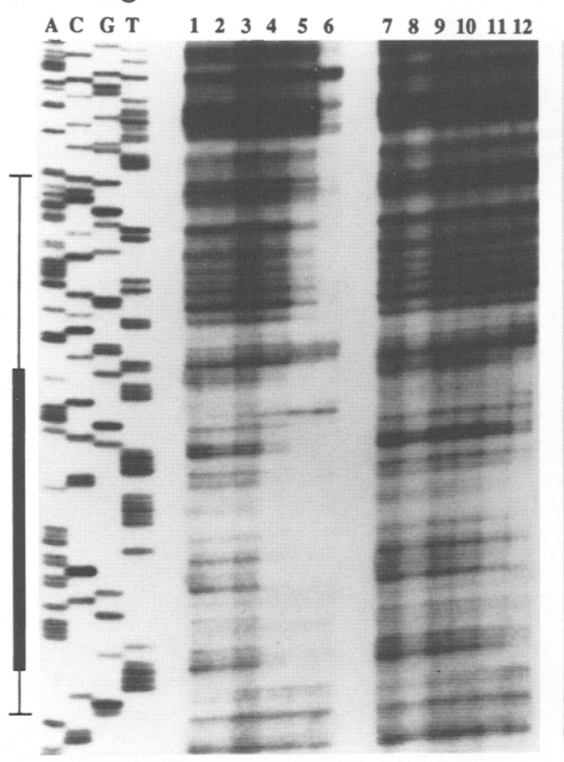

non-coding strand

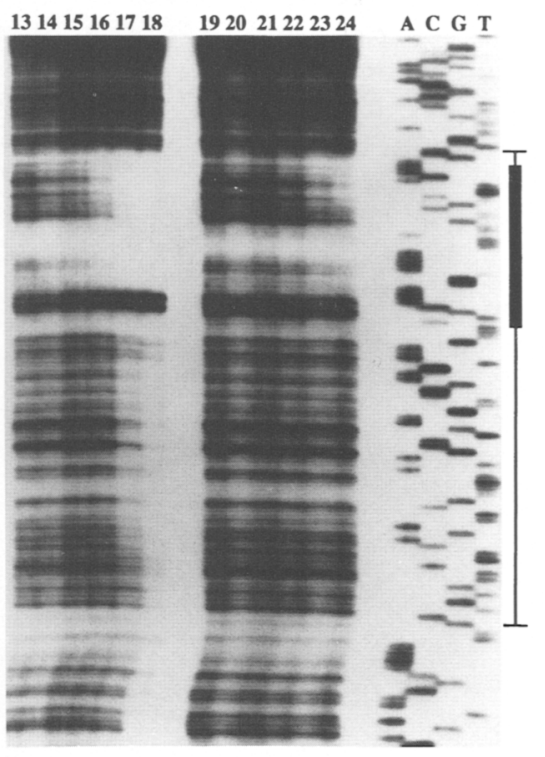

\section{b $\operatorname{deg} P$ site II coding strand}

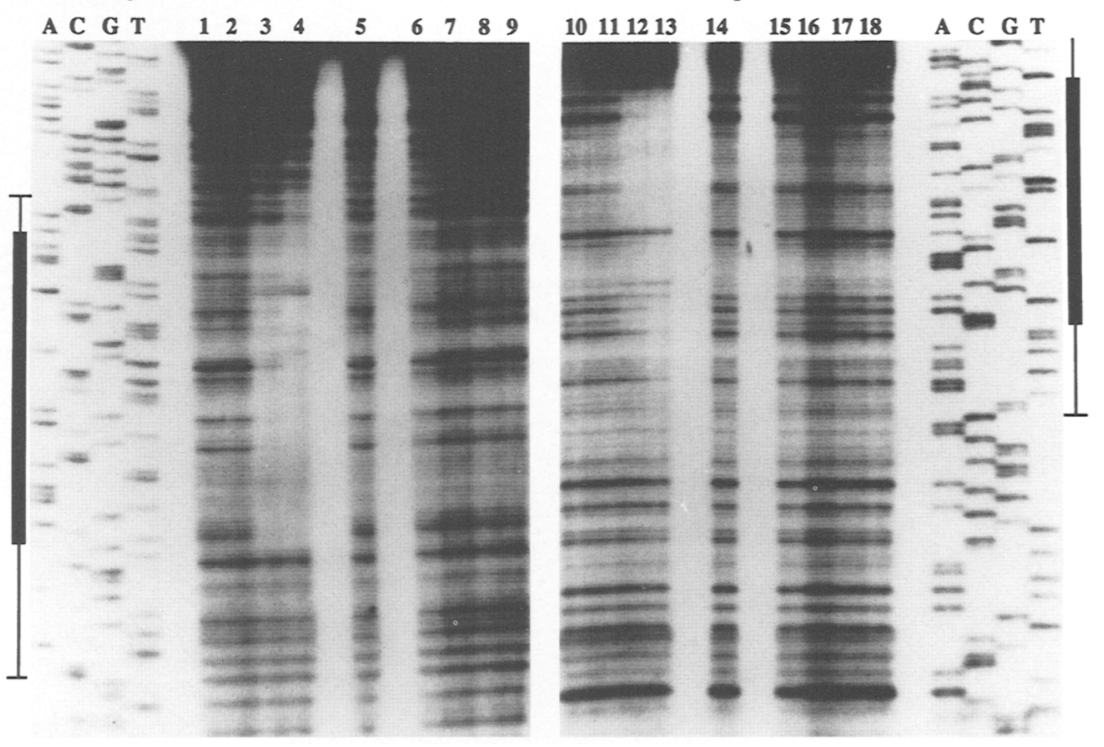

C
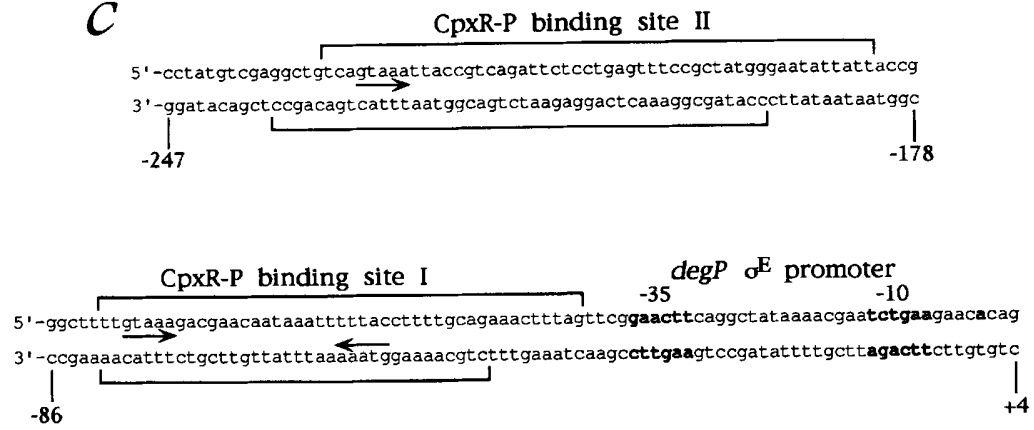
single site in the transcriptional regulatory region of the yihE-dsbA operon. Figure 7a shows DNase I footprinting analysis of the binding of the $\mathrm{His}_{6}-\mathrm{CpxR}$ and $\mathrm{His}_{6}-$ CpxR-P proteins to a 275-bp fragment (derived from pBTKSdsbA2) that includes the P2 promoter of the yihE$d s b A$ operon. DNase I footprints are readily apparent on the noncoding strand with the lowest concentration of $\mathrm{His}_{6}-\mathrm{CpxR}-\mathrm{P}$ used ( $\left.36 \mathrm{nM}\right)$, whereas equivalent footprints are only observed with the $\mathrm{His}_{6}-\mathrm{CpxR}$ protein at the highest concentration of protein employed ( $720 \mathrm{nM})$. As the concentration of the His ${ }_{6}$-CpxR-P protein is increased, the region of protection from DNase I cleavage expands bidirectionally. Significant differences in the apparent affinities of the $\mathrm{His}_{6}-\mathrm{CpxR}$ and $\mathrm{His}_{6}-\mathrm{CpxR}-\mathrm{P}$ proteins are also indicated by the DNase I footprints obtained on the coding strand (lanes 1-12); a core $\mathrm{His}_{6}-$ CpxR-P footprint is indicated in Figure $7 \mathrm{~b}$.

Computer-assisted alignments of the DNA sequences present in the three core footprints characterized to this point yielded only a pentamer motif $\left(5^{\prime}\right.$-GTAAA- 3 ; indicated with arrows in Figs. $6 \mathrm{c}$ and $7 \mathrm{~b}$ ) as the most significant primary sequence element present in all three sequences. In the case of the yihE-dsbA site, it was noted that a second imperfect copy of the motif $15^{\prime}$ GTAAG-3') was present in close proximity with only 5 bp (or half a helical turn) located between them (also indicated in Fig. 7b). A computer search of the E. coli genomic DNA sequences present in GenBank (release 96.0) with the sequences $5^{\prime}$-GTAA(N) ${ }_{6}$ GTAA-3' and $5^{\prime}$ GTAA $(N)_{7}$ GTAA-3' revealed the presence of a number of these elements, as would be expected given the relatively low complexity of the search motifs. However, subsequent analysis indicated that the presence of a subset of the motifs identified may be of physiological significance because they were present in known (or putative) transcriptional regulatory regions of genes encoding products related to protein folding.

\section{Binding of $\mathrm{His}_{6}-\mathrm{CpxR}$ and $\mathrm{His}_{6}-\mathrm{Cpx}$-P proteins to the transcriptional regulatory region of the ppiA gene}

In the yihE-dsbA operon promoter, the 5'-GTAAA$(\mathrm{N})_{5}$ GTAA-3' sequence is located $6 \mathrm{bp}$ upstream of the -35 element of the $\sigma^{70}$ promoter. This same element was found to be located $5 \mathrm{bp}$ upstream of the -35 element of the major $\sigma^{70}$ promoter $(\mathrm{P} 1)$ of the ppiA gene (Norregaard-Madsen et al. 1994) that encodes a periplasmic PPIase of the cyclophilin family (Liu and Walsh 1990; Hacker and Fischer 1993; Clubb et al. 1994). A definitive role for the PpiA protein in protein folding in the periplasmic compartment has yet to be demonstrated (Kleerebezem et al. 1995); however, as the products encoded by the two other transcriptional activation targets of CpxR-P ( $\operatorname{deg} P$ and $d s b A$ ) have distinct roles in the $a$

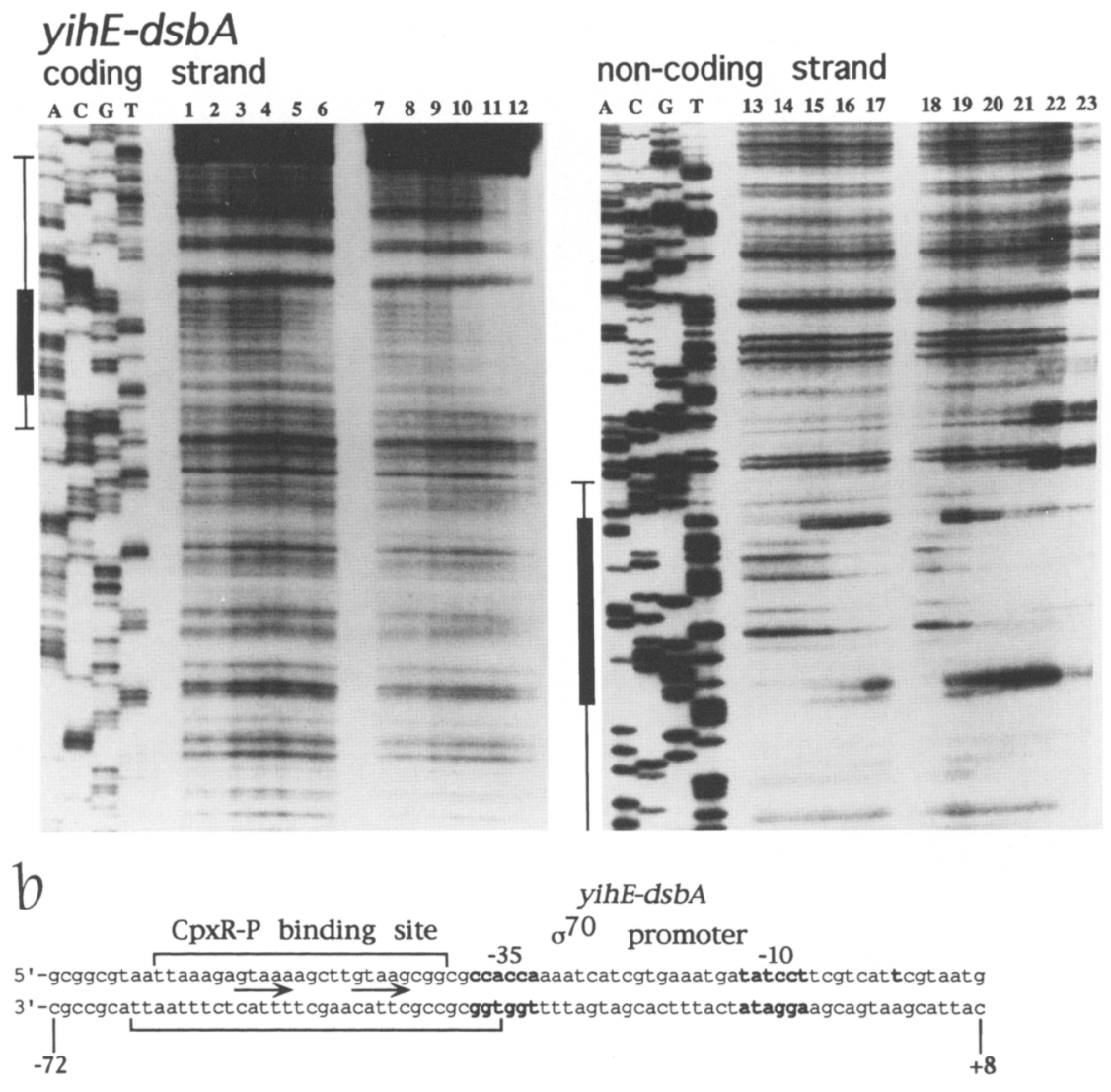

Figure 7. (a) DNase I protection assays of the binding of $\mathrm{His}_{6}-\mathrm{CpxR}$ and $\mathrm{His}_{6}$ CpxR-P to the promoter of the yihE-dsbA operon. A 275-bp DNA fragment /obtained by amplification of the $y i h E-d s b A$ promoter region of $\mathrm{pBTKSdsbA2}$ with primers DSBA3 and DSBA2) was end-labeled with ${ }^{32} \mathrm{P}$, and uniquely labeled substrates were generated by EcoRI (lanes 1-12) or BamHI (lanes 13-23) digestion. The substrate DNA was present at $\sim 2 \mathrm{nM}$ in reactions that also contained no added protein (lanes 1,7, 13,18), $36 \mathrm{nM} \mathrm{His}_{6}$-CpxR-P (lanes 8,19), 90 nM His ${ }_{6}-$ CpxR-P (lanes 9,20), 180 nM His $_{6}-$ CpxR-P (lanes 10,21), $360 \mathrm{nM} \mathrm{His}_{6}$-CpxR-P (lanes 11,22), $720 \mathrm{nM} \mathrm{His}_{6}$-CpxR-P (lanes 12,23), $36 \mathrm{~nm} \mathrm{His}_{6}$-CpxR (lane 2), $90 \mathrm{~nm}$ $\mathrm{His}_{6}$-CpxR (lanes 3,14), $180 \mathrm{nM} \mathrm{His}_{6}-\mathrm{CpxR}$

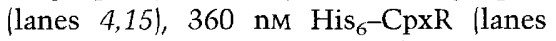
5,16), or $720 \mathrm{~nm} \mathrm{His}_{6}-\mathrm{CpxR}$ (lanes 6,17). Sequencing ladders were generated by extension of ${ }^{32} \mathrm{P}$-end-labeled DSBA3 primer for the coding strand or DSBA2 primer for the noncoding strand using pBTKSdsbA2 as a template. The core $\mathrm{His}_{6}-\mathrm{CpxR}-\mathrm{P}$ binding site is indicated by the thick line; the thin line indicates the limits of the sequence shown in $b$. $(b)$ The location of CpxR-P binding sites in the promoter region of the $y i h E-d s b A$ operon. Elements of the putative $\sigma^{70}$ promoter (Belin and Boquet 1994) are indicated; the core CpxR-P binding site is indicated by the brackets. 
processing or maturation of proteins in the periplasm, it was of interest to determine whether the ppiA gene may also be a member of the Cpx regulon.

EMS and DNase I footprinting studies suggested that phosphorylated CpxR binds to a single site in the transcriptional regulatory region of the ppiA gene. Figure $8 \mathrm{a}$ shows DNase I footprinting analysis of the binding of the $\mathrm{His}_{6}-\mathrm{CpxR}$ and $\mathrm{His}_{6}-\mathrm{CpxR}-\mathrm{P}$ proteins to a 267-bp fragment (derived from pBTKSppiA1) that includes the P1 promoter of the ppiA gene (Norregaard-Madsen et al. 1994). Under the conditions used in this analysis, clear DNase I footprints are readily apparent on the noncoding strand with the lowest concentration of $\mathrm{His}_{6}-\mathrm{CpxR}-\mathrm{P} / 36$ $\mathrm{nM}$ ), whereas equivalent footprints are only observed with the highest concentration of unphosphorylated $\mathrm{His}_{6}-\mathrm{CpxR}$ (360 nM). As the concentration of the $\mathrm{His}_{6}-$ CpxR-P protein is increased, the region of protection from DNase I cleavage again expands in a bidirectional fashion; a core $\mathrm{His}_{6}$ - CpxR-P footprint is indicated in Figure $8 b$.

\section{Cpx regulates transcription of the ppiA gene}

If the CpxR-P binding site in the ppiA promoter region is of physiological significance, then changes in expression of the ppiA gene may be expected to be observed under conditions that activate the Cpx pathway. We therefore studied changes in the levels of RNA transcripts originating from the P1 promoter after induction of NlpE overexpression; the quantitated data is shown in Figure $3 \mathrm{~b}$. Expression from the ppiA P1 promoter is induced 2.5-fold when NlpE is overexpressed in strains containing a wild-type $c p x R A$ operon but not in strains in which the $c p x$ operon is deleted. This level of induction is lower than that seen for the yihE-dsbA operon, which was induced 5- to 10 -fold in the same experiment.

To more definitively establish the role that the $\mathrm{Cpx}$ system plays in regulating the expression of the ppiA gene, we then examined the effect that various $c p x$ mutations have on the expression of the ppiA P1 promoter. Three independent cultures of each strain containing either the wild-type $c p x$ operon, the defined $c p x R A$ null mutation, or one of two $c p x A^{\star}$ mutations were grown at $37^{\circ} \mathrm{C}$, and the in vivo level of expression of the mRNA originating from the $\mathrm{P} 1$ promoter determined by RNase protection. The quantitated results were averaged and are shown in Figure $4 \mathrm{~b}$. Two strains containing different $c p x A^{*}$ mutations both express significantly more $(-2.5$ fold; $P<0.01, n=3$ ) of the ppiA Pl transcript relative to the $c p x^{+}$parent strain. In addition, we also reproducibly observed a two- to threefold decrease $(P<0.005, n=3)$ in expression of the $\mathrm{P} 1$ promoter in the $c p x$ null mutant
Figure 8. (a) DNase I protection assays of the binding of $\mathrm{His}_{6}-\mathrm{CpxR}$ and $\mathrm{His}_{6}$ CpxR-P to the ppiA promoter region. A 267-bp DNA fragment lobtained by amplification of the ppiA region of pBTKSppiA1 with primers PPIA1 and PPIA2) was endlabeled with ${ }^{32} \mathrm{P}$, and uniquely labeled substrates were generated by EcoRI (lanes 1-9) or BamHI \{lanes 10-18\} digestion. The substrate DNA was present at $\sim 2 \mathrm{nM}$ in reactions that also contained no added protein (lanes 1,10), $36 \mathrm{nM} \mathrm{His}_{6}$-CpxR-P (lanes 2,11), $90 \mathrm{nM} \mathrm{His}_{\sigma}-\mathrm{CpxR}-\mathrm{P}$ (lanes 3,12), $180 \mathrm{nM} \mathrm{His}{ }_{6}$-CpxR-P (lanes 4,13), $360 \mathrm{nM} \mathrm{His}_{6}$-CpxR-P (lanes 5,14), $36 \mathrm{~nm}$ $\mathrm{His}_{6}-\mathrm{CpxR}\left\{\right.$ lanes 6,15), $90 \mathrm{nM} \mathrm{His}_{6}-\mathrm{CpxR}$ (lanes 7,16), $180 \mathrm{nM} \mathrm{His}{ }_{6}-\mathrm{CpxR}$ (lanes 8,17), $360 \mathrm{~nm} \mathrm{His}_{6}$-CpxR (lanes 9,18). Sequencing ladders were generated by extension of ${ }^{32} \mathrm{P}$-end-labeled PPIAl primer for the coding strand or PPIA2 for the noncoding strand using pBTKSppiAl as a template. The core $\mathrm{His}_{6}$-CpxR-P binding site is indicated by the thick line; the thin line indicates the limits of the sequence shown in $b$. (b) The location of CpxR-P binding sites in the $\sigma^{70} \mathrm{P} 1$ promoter region of the ppiA gene. Elements of the putative $\sigma^{70} \mathrm{P} 1$ promoter (Norregaard-Madsen et al. 1994; this paper) are indicated; the core CpxR-P binding site is indicated by the brackets. a ppiA

\section{coding strand}

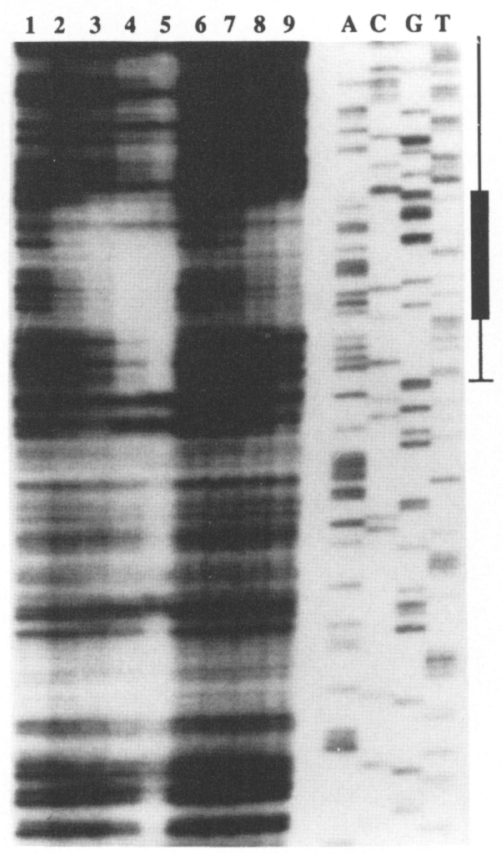

b

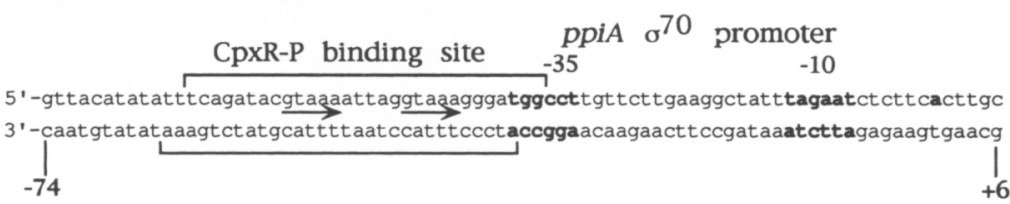

non-coding strand

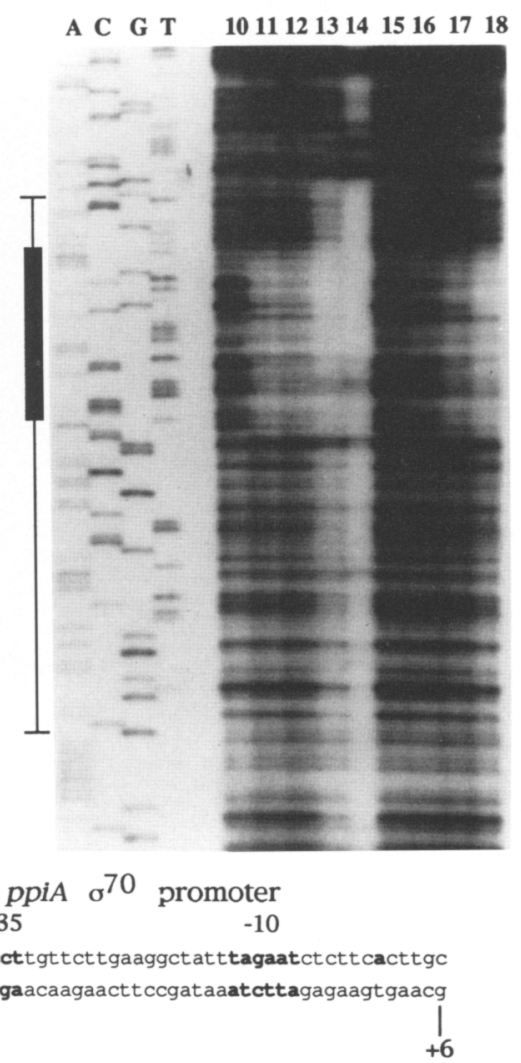


(Fig. 4b). The effects that $c p x$ mutations have on the expression of the ppiA $\mathrm{Pl}$ promoter (Figs. $3 \mathrm{~b}$ and $4 \mathrm{~b}$ ), taken together with results from DNase I footprinting (Fig. 8), suggest that the ppiA gene is a member of the Cpx regulon.

\section{Discussion}

New targets of the Cpx signal transduction pathway

Evidence presented here suggests that CpxA and CpxR directly regulate the expression of genes encoding periplasmic proteins required for protein folding and degradation. When the Cpx pathway is activated by $c p x A^{*}$ mutations or by NlpE overexpression, DsbA and DegP are coordinately induced. Elevated expression of DsbA is attributable to increased transcription of the P2 promoter of the yihE-dsbA operon. The phosphorylated form of CpxR binds with significantly higher affinity than the unphosphorylated form to specific sequences within the transcriptional regulatory regions of the $\operatorname{deg} P$ gene, the ppiA gene, and the yihE-dsbA operon. Transcriptional activation of these genes is therefore likely to be mediated by phosphorylation of CpxR by CpxA.

\section{Identification of a consensus sequence for $C p x R$ binding}

Analysis of the sequences of the $\operatorname{deg} P$ and $d s b A$ promoters to which the His-tagged CpxR-P protein bound resulted in the identification of a putative consensus binding site for CpxR at $\sigma^{70}$ promoters of $5^{\prime}-\mathrm{GTAAN}_{(6-}$ 7)GTAA-3'. Using this sequence, we identified the ppiA gene, encoding a periplasmic PPIase, as a potential regulatory target. The results of DNA binding and expression studies suggest that the phosphorylated form of the CpxR protein (CpxR-P) directly serves as a transcriptional activator of the $\mathrm{P} 1\left(\sigma^{70}\right)$ promoter of the ppiA gene. However, Cpx-dependent induction of the ppiA transcript is lower than that observed for the $d s b A$ or $\operatorname{deg} P$ genes, and deletion of the $c p x$ operon leads to a 2.5 -fold decrease in ppiA Pl promoter expression. Hence, the Cpx system appears to contribute to the basal level of expression of the ppiA P1 promoter under normal growth conditions, suggesting that the unphosphorylated form of CpxR may be capable of binding to, and activating transcription from, the ppiA $\mathrm{P} 1$ promoter in vivo. Alternatively, a low level of the phosphorylated form of CpxR may be present in cells in "unstimulated" growth conditions. A similar conclusion can be drawn from the results of a previous study, as expression of the $\operatorname{deg} P$ promoter was observed to be reproducibly lower in strains deleted for the $c p x$ operon (Danese et al. 1995).

\section{Mechanism of CpxR-mediated transcriptional activation}

The results obtained are compatible with the notion that CpxR-P serves in a direct fashion as a transcriptional activator of the $\sigma^{\mathrm{E}}$ promoter of the $\operatorname{deg} P$ locus. By analogy with observations on the mechanisms by which other prokaryotic transcriptional activators function (Busby and Ebright 1994), it seems likely that CpxR-P bound at the degP promoter-proximal binding site (site I) may facilitate recruitment of $\sigma^{\mathrm{E}}$-containing RNA polymerase holoenzyme by interacting with the carboxy-terminal domain of the $\alpha$-subunit. The upstream CpxR-Pbinding site (site II) is absent in the $\Phi(\operatorname{deg} P-l a c Z)$ construct used in previous studies (Danese et al. 1995). Because we find no obvious discrepancies between our results obtained by examining the expression of DegP protein and those obtained using the $\operatorname{deg} P-1 a c Z$ fusion, we cannot currently say how site II contributes to $\operatorname{deg} P$ expression.

The location of the DNase I footprints in the ppiA and $y i h E-d s b A$ promoter regions suggests that transcriptional activation may be mediated by interaction of CpxR-P with the $\sigma^{70}$ subunit of RNA polymerase holoenzyme, as is proposed for $\lambda$ cI protein-mediated activation at the $\lambda_{\text {PRM }}$ promoter (Joung et al. 1994; Li et al. 1994), or via interaction with both the carboxy- and amino-terminal domains of the $\alpha$-subunit as proposed for the catabolite activator protein at class II promoters ( Niu et al. 1996). Hence, CpxR-P appears able to activate transcription of promoters recognized by both $\sigma^{\mathrm{E}}(\operatorname{deg} P)$ and $\sigma^{70}$ (ppiA and yihE-dsbA) containing RNA polymerase holoenzymes.

\section{Are other periplasmic protein-folding catalysts members of the Cpx regulon?}

The identification of additional genes containing the consensus CpxR-binding site may help to further elaborate the Cpx regulon. For example, the regulatory region of the surA gene, the expression of which was not affected by $c p x A^{\star}$ mutations, does not contain the putative consensus sequence. Other genes such as $d s b B$, $d s b C$, and $d s b D$ also lack obvious matches to the consensus sequence. However, a search of the E. coli genome database demonstrates that this sequence is located in the transcriptional regulatory regions of a number of potentially relevant genes, such as rpoE, rpoH, groE, and $s k p(o m p H)$. As is shown in Figure 9, the $5^{\prime}$ -

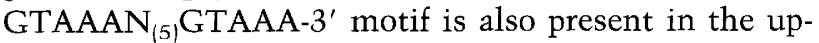
stream regulatory region of the $c p x R A$ operon, suggesting that the operon maybe subject to positive feedback regulation.

\section{Potential significance of the Cpx regulon}

Several results suggest that increased expression of periplasmic folding catalysts effected by CpxA and CpxR may promote the folding or repair of cell envelope proteins. For example, overexpression of DsbA can suppress many of the phenotypes associated with a $d s b B$ null mutation (Bardwell et al. 1993). Thus, although mutants deleted for the $c p x$ operon are not defective in disulfide bond formation, it seems likely that under some conditions, DsbA induction by Cpx may promote disulfide 
Figure 9. Alignment of the $\sigma^{70}$ promoters of the yihE-dsbA, ppiA, and $c p x R A$ operons. The putative " -35 " and " -10 " elements of the promoters are underlined, as are the bases corresponding to the sites of transcription initiation (yihE-dsbA and ppiA). Identity between the sequences are indicated (through the -35 element) with a ":" symbol.

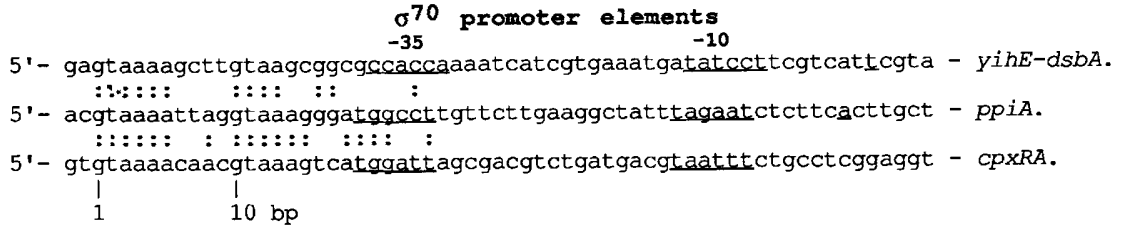

bond formation. Furthermore, in vitro experiments show that the presence of a PPIase can increase the efficiency of a disulfide bond isomerase (Schonbrunner and Schmid 1992). Hence, the PPIase PpiA, which appears to be coordinately regulated with DsbA by Cpx, may enhance the catalytic efficiency of DsbA or other as yet to be identified protein disulfide isomerases. Increased expression of DegP may be necessary to degrade proteins that are inappropriately folded or which cannot be repaired following oxidative (or other) damage.

\section{Does Cpx play a role in virulence?}

The Cpx system may come into play when the cell experiences environmental conditions that affect protein folding, such as those that are thought to be encountered by certain enterobacteriaceae in host tissues during infection. For example, a variety of immune cells produce reactive oxygen species $\left(\mathrm{NO}, \mathrm{O}_{2}{ }^{-}\right)$that can cause significant oxidative damage to proteins (Badwey and Karnovsky 1980; Nathan and Hibbs 1991; Babior 1992; Marletta 1993). Several studies have demonstrated that $\mathrm{DegP}$ is required for normal resistance to reactive oxygen species and is necessary for both survival in macrophages and full virulence in mice (Johnson et al. 1991; Baumler et al. 1994; Elzer et al. 1994). Hence, it seems possible that the Cpx-dependent expression of DegP may contribute to the protection of the cell from the damaging effects of free radical oxygen species by proteolytically degrading damaged proteins in the cell envelope (Boucher et al. 1996; Govan and Deretic 1996). It will be of interest to ascertain if free radical damage of cell envelope proteins is one of the stimuli that leads to activation of the CpxRA system.

Mutations in some of the other genes of the Cpx regulon also result in attenuation of pathogenesis in vivo. In Shigella sonnei, the Cpx system regulates expression of the virF gene in response to $\mathrm{pH}$ changes (Nakayama and Watanabe 1995). VirF is a transcriptional activator that positively regulates expression of the IpaB, IpaC, and IpaD proteins, which are important for invasion of epithelial cells (Menard et al. 1996). Expression and proper folding of these proteins requires DsbA, and $S$. flexneri $d s b A$ mutants are attenuated for invasion (Watarai et al. 1995). A DsbA homolog in Vibrio cholera is needed for the maturation of secreted virulence factors (Peek and Taylor 1992). It therefore seems possible that the Cpx system also regulates a variety of genes encoding products that are not directly involved in processes related to

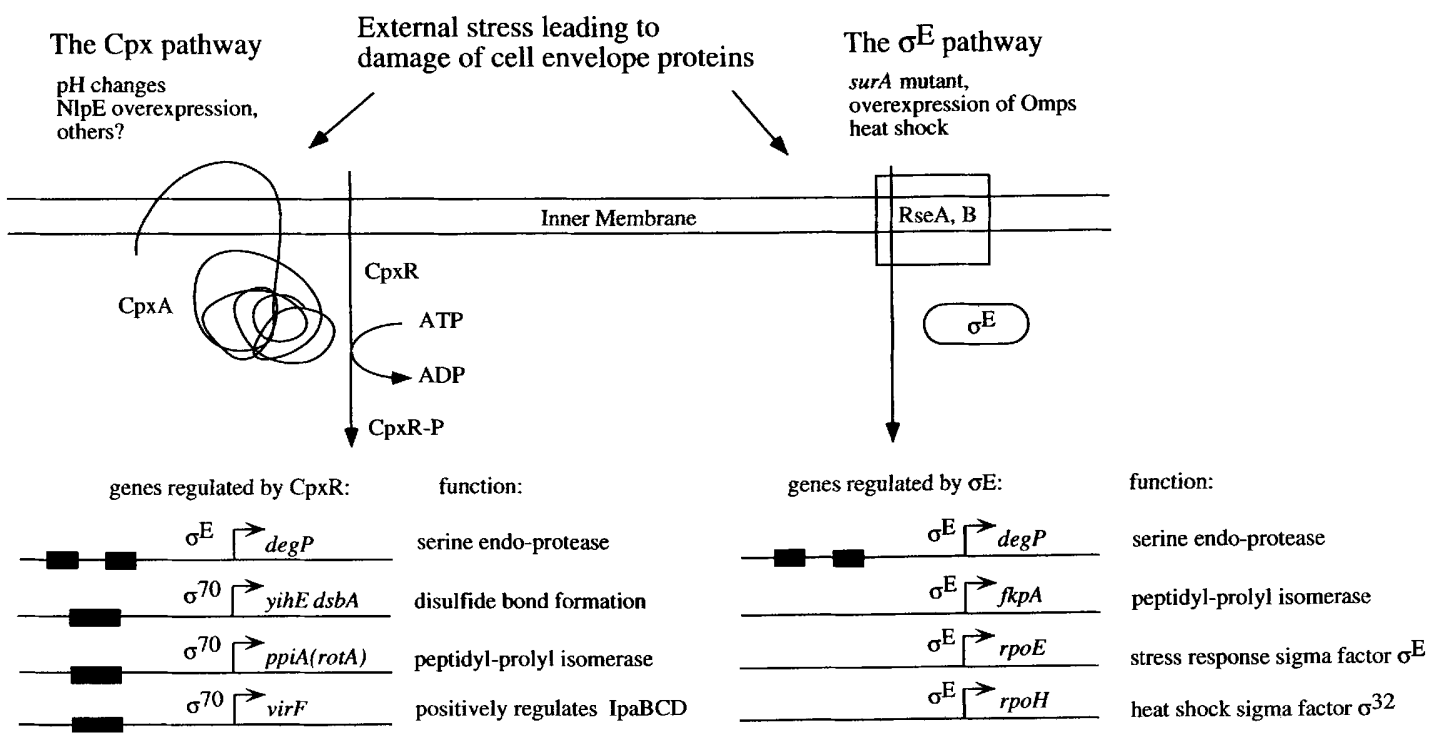

Figure 10. A model showing the Cpx regulon and other proteins implicated in responding to cell envelope stress. See Discussion for details. 
protein folding but that play important roles during pathogenesis.

\section{Relationship between the Cpx and $\sigma^{E}$ pathways}

These findings and how they relate to results in the accompanying paper (Danese and Silhavy, this issue) are summarized in Figure 10. E. coli contains at least two periplasmic stress response systems, the Cpx pathway and the $\sigma^{\mathrm{E}}$ pathway. The $\sigma^{\mathrm{E}}$ pathway is induced by conditions that lead to misfolding or misassembly of outer membrane proteins (Omps), such as overexpression of Omps or inactivation of the surA gene (Mecsas et al. 1993; Rouviere et al. 1995). Stress signals from the cell envelope are communicated to $\sigma^{\mathrm{E}}$ by the Rse proteins (De Las Peñas 1997). In response to these stresses, $\sigma^{\mathrm{E}}$ transcribes the $\operatorname{deg} P$ gene and a gene encoding another periplasmic PPIase, $f k p A$ (see Danese and Silhavy, this issue). The $\mathrm{Cpx}$ pathway responds to cell envelope stresses such as changes in $\mathrm{pH}$ or NlpE overexpression and activates the transcription of genes transcribed from both $\sigma^{70}$ and $\sigma^{\mathrm{E}}$ promoters (Danese et al. 1995; Nakayama and Watanabe 1995; Danese and Silhavy, this issue). The Cpx regulon includes at least $d s b A, \operatorname{deg} P$, and ppiA and possibly also virF and $c p x R A$, all of which contain sequences similar to the $\mathrm{CpxR}$ consensus sequence (solid boxes in Fig. 10) upstream of their promoters. The $\mathrm{Cpx}$ and $\sigma^{\mathrm{E}}$ pathways, which appear to respond to different stresses and generally regulate different genes, overlap to control the expression of the $\operatorname{deg} P$ gene. The presence of a putative CpxR-binding site in the regulatory regions of several members of the $\sigma^{\mathrm{E}}$ regulon may indi- cate that the $\mathrm{Cpx}$ and $\sigma^{\mathrm{E}}$ regulons form a network of overlapping and possibly closely integrated regulatory pathways.

\section{Materiais and methods}

\section{Bacterial strains}

The relevant genotypes of the bacterial strains used in this study are listed in Table 1 . Three different $c p x A^{\star}$ alleles were used in this study. The $c p x A 9$ mutant is temperature sensitive, exhibiting $c p x A^{\star}$ phenotypes at $42^{\circ} \mathrm{C}$ but not at $30^{\circ} \mathrm{C}$. The other two mutants, $c p x A 2.1$ and $c p x A 9.4$, are phenotypically more severe than the $c p x A 9$ mutant and exhibit $c p x A^{\star}$ phenotypes at both $23^{\circ} \mathrm{C}$ and $42^{\circ} \mathrm{C}$.

\section{Immunoprecipitation of radiolabeled proteins}

The rates of synthesis of DsbA, DegP, SurA, MBP, and OmpA were determined by pulse-chase immunoprecipitation experiments. Strains were grown at the indicated temperatures in M63 medium containing $0.2 \%$ maltose supplemented with 18 amino acids $(50 \mu \mathrm{g} / \mathrm{ml}$ each $)$. Cultures were given a 20 -sec pulse of $\left.{ }^{35} \mathrm{~S}\right] \mathrm{methionine}(100 \mu \mathrm{Ci} / \mathrm{ml})$ and chased with excess, unlabeled methionine. Samples were taken after $1 \mathrm{~min}$ of chase, and the labelings were stopped on ice. Immunoprecipitation of radiolabeled proteins was carried out essentially as described (Pogliano and Beckwith 1993). Rabbit polyclonal antibodies specific for each protein, DsbA (Bardwell et al. 1993), DegP, SurA (a gift of S. Lazar and R. Kolter, Harvard Medical School, Boston, $\mathrm{MA})$, and OmpA were used for immunoprecipitations. DegP, SurA, MBP, and OmpA were separated by $10 \%$ SDS-PAGE. DsbA and OmpA were separated by $12.5 \%$ SDS-PAGE. The counts in each radioactive band were quantitated using a Molecular Dynamics Phosphorimager. Counts in the DegP and DsbA bands were normalized to OmpA as an internal control

Table 1. Strains and plasmids

\begin{tabular}{|c|c|c|}
\hline & Relevant genotype & Reference \\
\hline \multicolumn{3}{|l|}{ Strain } \\
\hline ECL525 & MC4100 $\Delta(\operatorname{argF}-1 a c) U 169$ araD139 & Iuchi and Lin (1988) \\
\hline ECL3000 & MC4100 $\Delta(r h a-c p x R A-p f k A) 15$ zig-1::Tn10 & A.S. Lynch and E.C.C. Lin (unpubl.) \\
\hline JP406 & ECL525 F'pOXgen & J. Dong, J. Pogliano, and E.C.C. Lin (unpubl.) \\
\hline ECL1212 & $\mathrm{JP} 406 \Delta(c p \times R A) 2$ & J. Dong, J. Pogliano, and E.C.C. Lin (unpubl.) \\
\hline JP408 & JP406 zii::Tn10 cpxA9 & this study \\
\hline JP313 & MC4100 ara $\Delta 714$ & this study \\
\hline $\mathrm{JP} 444$ & $\mathrm{JP} 313 / \mathrm{pDB} 3$ & this study \\
\hline JP445 & JP313/pBAD22 & this study \\
\hline JP446 & JP313/pND18 & this study \\
\hline JP466 & JP406 argE::Tn10 & this study \\
\hline JP467 & JP406 $\arg E:: \operatorname{Tn} 10$ cpxA2.1 & this study \\
\hline JP468 & JP406 $\arg E:: \operatorname{Tn} 10$ cpxA9.4 & this study \\
\hline ECL1215 & JP406 ara ${ }^{+}$ & this study \\
\hline ECL1216 & ECL1212 $\mathrm{ara}^{+}$ & this study \\
\hline JP472 & ECL1215/pBAD22 & this study \\
\hline JP474 & ECL1216/pBAD22 & this study \\
\hline JP558 & ECL1215/pND18 & this study \\
\hline JP560 & ECL1216/pND18 & this study \\
\hline \multicolumn{3}{|l|}{ Plasmid } \\
\hline pBAD22 & bla, pBR ori, Pbad promotor & Guzman et al. (1995) \\
\hline pND1 8 & overexpresses NlpE & Danese et al. (1995) \\
\hline pDB3 & overexpresses alkaline phosphatase & Guzman et al. $\{1995\}$ \\
\hline
\end{tabular}


and expressed in arbitrary units. OmpA is expressed constitutively at high levels, and its expression is not affected by the conditions used here; similar results were obtained if DegP or DsbA expression was normalized to the culture $\mathrm{OD}_{600}$ at the time of sampling. To ensure that the DegP protein : munoprecipitated in these experiments is encoded by the $\operatorname{deg} P$ gene, a cpxA9 $\operatorname{deg} P \because: \operatorname{Tn} 5$ double mutant was also examined; no protein that migrates at the position of DegP was seen in this strain (data not shown).

\section{Plasmid constructions}

Plasmids pQE30 and pREP4 were obtained from Qiagen Ltd. To create pQE30CpxR, a 700-bp region of DNA containing the cpxR open reading frame (positions 1246-1946 in GenBank file L14579) was amplified by PCR with primers CPXR5 (5'CCCGGATCCCATATGAATAAAATCCTGTTAGTTGATG$\left.3^{\prime}\right)$ and CPXR3 (5'-CCCGGATCCTGCAGTTATCATGAAGCAGAAACCATCAG-3') using E. coli MC4100 DNA as a template. The PCR product was digested with $B a m H I$ and $P$ stI , and the resulting 710 -bp fragment was cloned between the corresponding sites of pQE30. pQE30cpxR, expresses a CpxR fusion protein, composed of full-length $\mathrm{CpxR}$ with an amino-terminal Met-Arg-Gly-Ser-(His) ${ }_{6}$-Gly-Ser-His-extension, under transcriptional control of an isopropyl-thiogalactoside (IPTG)-regulated phage T5 promoter.

In the following series of constructions, the pairs of oligonucleotides described were used to amplify the indicated regions of E. coli MC4 100 genomic DNA, and the PCR products were cloned between the BamHI and EcoRI sites of pBluescript II KS(-); sequence verification of the cloned, amplified DNA was performed in all cases. pBTKSdegPl contains a 353-bp segment of the $\operatorname{deg} P$ promoter region (positions 69180-69533 in GenBank file D26562), amplified with primers DEGP1 (5'-CCGGATCCGCCATCGGCTGGCCTATGTC-3' $)$ and DEGP2 $\left\{5^{\prime}\right.$ CCGAATTCGCCAAACCTAAACTCAGACC-3'). pBTKSdegP2 contains a 235 -bp segment of the $\operatorname{deg} P$ promoter region (positions 69298-69533 ), amplified with primers DEGP3 (5' -GGGGATCCGACCTCTATGCGTGGGATG-3') and DEGP2 (5'-CCGAATTCGCCAAACCTAAACTCAGAGCC-3'). pBTKSdegP3 contains a 201-bp segment of the $\operatorname{deg} P$ promoter region (positions 69143-69344), amplified with primers DEGP4 (5'-CGGGATCCCTATTGAATCGCGCTTATTCCAC-3') and DEGP5 (5'-GGGAATTCTACGGCCATCAGACGTCGG-3'). pBTKSdsbA1 contains a 350-bp segment of the region upstream of the $y i h E-d s b A$ operon (Belin and Boquet 1994; positions 760-1110 in GenBank file X80762), amplified with primers DSBA1 $\left\{5^{\prime}\right.$-CCGGATCCTGAATGAAGTTATTGAACTCCTCC$\left.3^{\prime}\right)$ and DSBA2 (5'-CCGAATTCGTAAAAGCGCTGTTATTCATCCC-3'). pBTKSdsbA2 contains a 260 -bp segment of the region upstream of the yihE-dsbA operon (positions 850-1110) amplified with primers DSBA3 (5'-CCGGATCCAGGTTTTGACGGCGAACTGGC- $\left.{ }^{\prime}\right)$ and DSBA2 (5'-CCGAATTCGTAAAAGCGCTGTTATTCATCCC-3'). Finally, pBTKSppiAl contains a 253-bp segment of the ppiA promoter region (Kawamukai et al. 1989; positions 363-616 in GenBank file M28363) and was amplified with primers PPIA1 (5'-GGGGATCCAGGCGGCGATTTTAGGTG-3'\} and PPIA2 (5'-GGGAATTCCATCGCCGCCAGGGTCG-3').

Plasmid pDB7601 contains the 146-bp HindIII-BamHI fragment of pPB2234 (Belin and Boquet 1994) cloned in pBSKS; the DNA was linearized with HindIII and transcribed with T7 RNA polymerase. The 193-nucleotide cRNA yields a 95-nucleotide S1 nuclease-protected fragment after hybridization to yihE$d s b A$ mRNA initiated at the upstream, P2 promoter. Plasmid pDB5601 contains the 520-bp HindIII-BgIII fragment of
pPB3224 cloned between the BamHI and HindIII sites of pSP65; the DNA was linearized with $\mathrm{HpaI}$ and transcribed with SP6 RNA polymerase. The 414-nucleotide cRNA yields a $310-$ nucleotide protected fragment after hybridization to $d s b A$ mRNA initiated at the downstream, P1 promoter. A PCR-amplified ppiA DNA fragment (positions 273-697; Kawamukai et al. 1989; GenBank accession no. M28363) was restricted with EcoRI and PvuII and subcloned between the EcoRI and SmaI sites of pBSKS. Plasmid DNA was digested with DraI and transcribed with T7 RNA polymerase. The 355-nucleotide cRNA yields a 147-nucleotide protected fragment after hybridization to ppiA mRNA initiated at the P1 promoter (Norregaard-Madsen et al. 1994).

\section{RNA isolation}

Cells were grown in M63 medium supplemented with 18 amino acids $(50 \mu \mathrm{g} / \mathrm{ml} \mathrm{each}), 0.2 \%$ maltose and $0.4 \%$ glycerol, and induced with $0.2 \%$ arabinose for the indicated times. Plasmidbearing cells were grown in medium supplemented with 100 $\mu \mathrm{g} / \mathrm{ml}$ of ampicillin. Aliquots were labeled for $30 \mathrm{sec}$ with $\left.{ }^{35} \mathrm{~S}\right]$ methionine at the time of RNA isolation, and the lysates were immunoprecipitated with appropriate antibodies as described (Bost and Belin 1995). Culture samples (2 ml) were lysed by boiling for $2 \mathrm{~min}$ after addition of $0.2 \mathrm{ml}$ of $0.5 \mathrm{M}$ Tris- $\mathrm{HCl}$ (pH 8.1), 0.4\% SDS, and $20 \mathrm{~mm}$ EDTA (Belin et al. 1979). The lysates were made $0.2 \mathrm{M}$ with $\mathrm{NaOAc}(\mathrm{pH} 4.7)$, extracted twice with phenol/chloroform, and precipitated with ethanol after addition of one-sixth volume of glacial acetic acid. Nucleic acids were resuspended in $10 \mathrm{~mm}$ Tris- $\mathrm{HCl}(\mathrm{pH} 7.5), 20 \mathrm{~mm} \mathrm{NaCl}$, and $5 \mathrm{~mm} \mathrm{MgOAc}$, digested for $20 \mathrm{~min}$ at $37^{\circ} \mathrm{C}$ with 30 units of RNase-free DNase (Promega), extracted with phenol/ chloroform, and precipitated with ethanol. The RNA yield was $-50 \mu \mathrm{g}$ of cells $\left(A_{540}\right)$; the integrity of the RNAs was verified by electrophoresis.

\section{RNase protection}

The preparation of probes, hybridization, digestion of the unhybridized RNAs with RNase A, and analysis of the protected fragments were performed as described (Belin 1996a,b). The probes were labeled with $\left[{ }^{32} \mathrm{P}\right] \mathrm{UTP}$ in the presence of $100 \mu \mathrm{M}$ unlabeled UTP. For each sample, $2 \mu \mathrm{g}$ of cellular RNA was hybridized to $4 \mathrm{ng}$ of cRNA probe.

\section{DNA-binding studies}

Purification of the $\mathrm{His}_{6}-\mathrm{CpxR}$ protein from IPTG-induced $E$. coli ECL3000 cells transformed with pREP4 and pQE30CpxR was performed as described previously for a similarly tagged protein $\left(\mathrm{His}_{6}-\mathrm{ArcA}\right)$ of the two-component response regulator family (Lynch and Lin 1996). On average, $2.5 \mathrm{mg}$ of purified $\mathrm{His}_{6}$ - CpxR was obtained from 1 gram of cell paste. Phosphorylation of the protein for use in DNA-binding studies used a standard reaction in which $\mathrm{His}_{6}-\mathrm{CpxR}(100 \mu \mathrm{g} / \mathrm{ml}$ of final concentration/ was incubated for $1 \mathrm{hr}$ at $30^{\circ} \mathrm{C}$ in a buffer containing $100 \mathrm{~mm}$ Tris- $\mathrm{HCl}$ (pH 7.4), $10 \mathrm{~mm} \mathrm{MgCl} 2,125 \mathrm{mM} \mathrm{KCl}$, and 50 $\mathrm{mM}$ acetyl phosphate (lithium, potassium salt from Sigma). In parallel, similar reactions lacking acetyl phosphate were used to prepare $\mathrm{His}_{6}-\mathrm{CpxR}$ for use in DNA-binding studies. The conditions used for in vitro DNA-binding assays by EMS and DNase I footprinting assays were as described previously (Lynch and Lin 1996).

\section{Acknowledgments}

We are grateful to Pete Yorgey for helpful discussions, Paul Danese and Tom Silhavy for communicating results prior to 
publication, Phil Silverman for the gift of strains containing the cpxA9 mutation, Dana Boyd for help with DNA sequence database analysis, and Kit Pogliano for critical reading of the manuscript. D.B. thanks Filo Silva for expert technical help. This work was supported by National Institutes of Health grants to J.B. and E.C.C.L. (GM40993 and GM39693). D.B. was supported by the Fonds National Suisse de la Recherche Scientifique. J.B. is an American Cancer Society Research Professor.

The publication costs of this article were defrayed in part by payment of page charges. This article must therefore be hereby marked "advertisement" in accordance with 18 USC section 1734 solely to indicate this fact.

\section{References}

Babior, B.M. 1992. The respiratory burst oxidase. Enzymol. Rel. Areas Mol. Biol. 65: 49-65.

Badwey, J.A. and M.L. Karnovsky. 1980. Active oxygen species and the functions of phagocytic leukocytes. Annu. Rev. Biochem. 49: 695-726.

Bardwell, J.C.A., K. McGovern, and J. Beckwith. 1991. Identification of a protein required for disulfide bond formation in vivo. Cell 67: 581-589.

Bardwell, J.C.A., J. Lee, G. Jander, N. Martin, D. Belin, and J. Beckwith. 1993. A pathway for disulfide bond formation in vivo. Proc. Natl. Acad. Sci. 90: 1038-1042.

Baumler, A.J., J.G. Kusters, I. Stojiljkovic, and F. Heffron. 1994. Salmonella typhimurium loci involved in survival within macrophages. Infect. Immun. 62: 1623-1630.

Belin, D. 1996a. The preparation of riboprobes. Basic DNA and RNA protocols Methods Mol. Biol. 58: 83-91.

- 1996b. The RNase protection assay. Basic DNA and RNA protocols. Methods Mol. Biol. 58: 131-136.

Belin, D., J. Hedgpeth, G.B Selzer, and R.H. Epstein. 1979. Temperature-sensitive mutation in the initiation codon of the rIIB gene of bacteriophage T4. Proc. Natl. Acad. Sci. 76: 700704.

Belin, P. and P.L. Boquet. 1994. The Escherichia coli dsbA gene is partly transcribed from the promoter of a weakly expressed upstream gene. Microbiology 140: 3337-3348.

Bost, S. and D. Belin. 1995. A new genetic selection identifies essential residues in SecG, a component of the Escherichia coli protein export machinery. EMBO J. 14: 4412-4421.

Boucher, J.C., J. Martinez-Salazar, M.J. Schurr, M.H. Mudd, and V. Deretic. 1996. Two distinct loci affecting conversion to mucoidy in Pseudomonas aeruginosa in cystic fibrosis encode homologs of the serine protease HtrA. J. Bacteriol. 178: $511-523$.

Busby, S. and R.H. Ebright. 1994. Promoter structure, promoter recognition, and transcription activation in prokaryotes. Cell 79: 743-746.

Clubb, R.T., S.B. Ferguson, C.T. Walsh, and G. Wagner. 1994. Three-dimensional solution structure of Escherichia coli periplasmic cyclophilin. Biochemistry 33: 2761-2772.

Cosma, C.L., P.N. Danese, J.H. Carlson, T.J. Silhavy, and W.B. Snyder. 1995. Mutational activation of the Cpx signal transduction pathway of Escherichia coli suppresses the toxicity conferred by certain envelope-associated stresses. Mol. Microbiol. 18: 491-505.

Danese, P.N. and T.J. Silhavy. 1997. The $\sigma^{\mathrm{E}}$ and the Cpx signal transduction systems control the synthesis of periplasmic protein-folding enzymes in Escherichia coli. Genes \& Dev. (this issue).

Danese, P.N., W.B. Snyder, C.L. Cosma, L.J.B. Davis, and T.J. Silhavy. 1995. The Cpx two-component signal transduction pathway of Escherichia coli regulates transcription of the gene specifying the stress-inducible periplasmic protease, DegP. Genes \& Dev. 9: 387-398.

De Las Peñas, A., L. Connolly, and C.A. Gross. 1997. The $\sigma^{\mathrm{E}}$ mediated response to extracytoplasmic stress in E. coli is transduced by RseA and RseB, two negative regulators of $\sigma^{\mathrm{E}}$. Mol. Microbiol. (in press).

Dong, J.M., S. Iuchi, H.S. Kwan, Z. Lu, and E.C.C. Lin. 1993. The deduced amino acid sequence of the cloned $c p x R$ gene suggests the protein is the cognate regulator for the membrane sensor, $\mathrm{CpxA}$, in a two-component signal transduction system of Escherichia coli. Gene 136: 227-230.

Elzer, P.H., R.W. Phillips, M.E. Kovach, K.M. Peterson, and R.M. Roop II. 1994. Characterization and genetic complementation of a Brucella abortus high-temperature-requirement A (htrA) deletion mutant. Infect. Immun. 62: 41354139.

Erickson, J.W. and C.A. Gross. 1989. Identification of the $\sigma^{\mathrm{E}}$ subunit of Escherichia coli RNA polymerase: A second alternate $\sigma$ factor involved in high-temperature gene expression. Genes \& Dev. 3: 1462-1471.

Govan, J.R. and V. Deretic. 1996. Microbial pathogenesis in cystic fibrosis: Mucoid Pseudomonas aeruginosa and Burkholderia cepacia. Microbiol. Rev. 60: 539-574.

Guilhot, C., G. Jander, N.L. Martin, and J. Beckwith. 1995. Evidence that the pathway of disulfide bond formation in Escherichia coli involves interactions between the cysteines of DsbB and DsbA. Proc. Natl. Acad. Sci. 92: 9895-9899.

Gupta, S.D., B.T.O. Lee, J. Camakaris, and H.C. Wu. 1995. Identification of cutC and cutF (nlpE) genes involved in copper tolerance in Escherichia coli. J. Bacteriol. 177: 4207-4215.

Guzman, L.M., D. Belin, M.J. Carson, and J. Beckwith. 1995. Tight regulation, modulation, and high-level expression by vectors containing the arabinose Pbad promoter. J. Bacteriol. 177: 4121-4130.

Hacker, J. and G. Fischer. 1993. Immunophilins: Structure-function relationship and possible role in microbial pathogenicity. Mol. Microbiol. 10: 445-456.

Hayano, T., N. Takahashi, S. Kato, N. Kaki, and M. Suzuki. 1991. Two distinct forms of peptidyl-prolyl-cis-trans-isomerase are expressed separately in periplasmic and cytoplasmic compartments of Escherichia coli cells. Biochemistry 30: $3041-3048$.

Horne, S.M. and K.D. Young. 1995. Escherichia coli and other species of the Enterobacteriaceae encode a protein similar to the family of Mip-like FK506-binding proteins. Arch. Microbiol. 163: 357-365.

Iuchi, S. and E.C.C. Lin. 1988. arcA (dye), a global regulatory gene in Escherichia coli mediating repression of enzymes in aerobic pathways. Proc. Natl. Acad. Sci. 85: 1888-1892.

Jander, G., N.L. Martin, and J. Beckwith. 1994. Two cysteines in each periplasmic domain of the membrane protein DsbB are required for its function in protein disulfide bond formation. EMBO I. 13: 5121-5127.

Johnson, K., I. Charles, G. Dougan, D. Pickard, O. O'Gaora, G. Costa, I. Miller, and C. Hormaeche. 1991. The role of stressresponse protein in Salmonella typhimurium virulence. Mol. Microbiol. 5: 401-407.

Joung, J., D. Koepp, and A. Hochschild. 1994. Synergistic activation of transcription by bacteriophage lambda cI protein and E. coli cAMP receptor protein. Science 265: 1863-1866.

Kamitani, S., Y. Akiyama, and K. Ito. 1992. Identification and characterization of an Escherichia coli gene required for the formation of correctly folded alkaline phosphatase, a periplasmic enzyme. EMBO J. 11: 57-62.

Kawamukai, M., H. Matsuda, W. Fujii, R. Utsumi, and T. Ko- 
mano. 1989. Nucleotide sequences of fic and fic-1 genes involved in cell filamentation induced by cAMP in Escherichia coli. J. Bacteriol. 171: 4525-4529.

Kleerebezem, M., M. Heutink, and J. Tommassen. 1995. Characterization of an Escherichia coli rotA mutant, affected in periplasmic peptidyl-prolyl cis/trans isomerase. Mol. Microbiol. 18: 313-320.

Lazar, S.W. and R. Kolter. 1996. SurA assists the folding of Escherichia coli outer membrane proteins. I. Bacteriol. 178: 1770-1773.

Li, M., H. Moyle, and M. Susskind. 1994. Target of the transcriptional activation function of phage lambda cI protein. Science 263: 75-77.

Lipinska, B., S. Sharma, and C. Georgopoulos. 1988. Sequence analysis and regulation of the $h t r A$ gene of Escherichia coli: A $\sigma^{32}$-independent mechanism of heat-inducible transcription. Nucleic Acids Res. 16: 10053-10067.

Liu, J. and C.T. Walsh. 1990. Peptidyl-prolyl cis-trans-isomerase from Escherichia coli: A periplasmic homolog of cyclophilin that is not inhibited by cyclosporin A. Proc. Natl. Acad. Sci. 87: 4028-4032.

Lynch, A.S. and E.C.C. Lin. 1996. Transcriptional control mediated by the ArcA two-component response regulator protein of Escherichia coli: Characterization of DNA binding at target promoters. J. Bacteriol. 178: 6238-6249.

Marletta, M.A. 1993. Nitric oxide synthase: Function and mechanism. Adv. Exp. Med. Biol. 338: 281-284.

Mecsas, J., P.E. Rouviere, J.W. Erickson, D.T.J., and C.A. Gross. 1993. The activity of the $\sigma^{\mathrm{E}}$, an Escherichia coli heat-inducible $\sigma$-factor, is modulated by expression of outer membrane proteins. Genes \& Dev. 7: 2618-2628.

Menard, R., C. Dehio, and P.J. Sansonetti. 1996. Bacterial entry into epithelial cells: The paradigm of Shigella. Trends Microbiol. 4: 220-226.

Missiakas, D., J. Betton, and S. Raina. 1996. New components of protein folding in extracytoplasmic compartments of Escherichia coli SurA, FkpA and Skp/OmpH. Mol. Microbiol. 21: 871-884.

Nakayama, S. and H. Watanabe. 1995. Involvement of $c p x A$, a sensor of a two-component regulatory system, in the $\mathrm{pH}$ dependent regulation of expression of Shigella sonnei virF gene. J. Bacteriol. 177: 5062-5069.

Nathan, C.F. and J.B. Hibbs. 1991. Role of nitric oxide synthesis in macrophage antimicrobial activity. Curr. Opin. Immunol. 3: $65-70$.

Niu, W., Y. Kim, G. Tau, T. Heyduk, and R.H. Ebright. 1996. Transcription activation at class II CAP-dependent promoters: Two interactions between CAP and RNA polymerase. Cell 87: 1123-1134.

Norregaard-Madsen, M., B. Mygind, R. Pedersen, P. ValentinHansen, and L. Sogaard-Andersen. 1994. The gene encoding the periplasmic cyclophilin homoloque, PPIase A, in Escherichia coli, is expressed from four promoters, three of which are activated by the cAMP-CRP complex and negatively regulated by the CytR repressor. Mol. Microbiol. 14: 989997.

Parkinson, J.S. and E.C. Kofoid. 1992. Communication modules in bacterial signaling proteins. Annu. Rev. Genet. 26: 71112.

Peek, J.A. and R.K. Taylor. 1992. Characterization of a periplasmic thiol:disulfide interchange protein required for the functional maturation of secreted virulence factors of Vibrio cholerae. Proc. Nat1. Acad. Sci. 89: 6210-6214.

Pogliano, K.J. and J. Beckwith. 1993. The Cs sec mutants of Escherichia coli reflect the cold sensitivity of protein export itself. Genetics 133: 763-773.
Rahfeld, J., A. Schierhorn, K. Mann, and G. Fischer. 1994. A novel peptidyl-prolyl cis/trans isomerase from Escherichia coli. FEBS Lett. 343: 65-69.

Raina, S., D. Missiakas, and C. Georgopoulos. 1995. The rpoE gene encoding $\sigma^{\mathrm{E}}\left(\sigma^{24}\right)$ heat shock sigma factor of Escherichia coli. EMBO J. 14: 1043-1055.

Rainwater, S. and P. Silverman. 1990. The Cpx proteins of Escherichia coli K-12: Evidence that $c p \times A$, ecfB, ssd, and eup mutations all identify the same gene. I. Bacteriol. 172: 24562461.

Rietsch, A., D. Belin, N. Martin, and J. Beckwith. 1996. An in vivo pathway for disulfide bond isomerization in Escherichia coli. Proc. Natl. Acad. Sci. 93: 13048-13053.

Roof, W.D., S.M. Horne, K.D. Young, and Y. Young. 1994. slyD, a host gene required for $\Phi \times 174$ lysis, is related to the FK506binding protein family of peptidyl-prolyl cis-trans isomerases. J. Biol. Chem. 269: 2902-2910.

Rouvière, P.E. and C.A. Gross. 1996. SurA, a periplasmic protein with peptidyl-prolyl isomerase activity, participates in the assembly of outer membrane porins. Genes \& Dev. 10: 3170-3182.

Rouvière, P.E., A. De Las Penas, J. Mecsas, C.Z. Lu, K.E. Rudd, and C.A. Gross. 1995. rpoE, the gene encoding the second heat-shock sigma factor, $\sigma^{\mathrm{E}}$, in Escherichia coli. EMBO $\mathrm{F}$. 14: 1032-1042.

Rudd, K.E., H.J. Sofia, E.V. Koonin, G. Plunkett III, S. Lazar, and P.E. Rouviere. 1995. A new family of peptidyl-prolyl isomerase. Trends Biochem. Sci. 20: 12-14.

Schonbrunner, E.R. and F.X. Schmid. 1992. Peptidyl-prolyl cistrans isomerase improves the efficiency of protein disulfide isomerase as a catalyst of protein folding. Proc. Natl. Acad. Sci. 89: 4510-4513.

Snyder, W.B., L.J. Davis, P.N. Danese, C.L. Cosma, and T.J. Silhavy. 1995. Overproduction of $\mathrm{NlpE}$, a new outer membrane lipoprotein, suppresses the toxicity of periplasmic LacZ by activation of the Cpx signal transduction pathway. J. Bacteriol. 177: 4216-4223.

Strauch, K.L. and J. Beckwith. 1988. An Escherichia coli mutation preventing degradation of abnormal periplasmic proteins. Proc. Natl. Acad. Sci. 85: 1576-1580.

Strauch, K.L., K. Johnson, and J. Beckwith. 1989. Characterization of $\operatorname{deg} P$, a gene required for proteolysis in the cell envelope and essential for growth of Escherichia coli at high temperature. I. Bacteriol. 171: 2689-2696.

Visick, J.E. and S. Clarke. 1995. Repair, refold, recycle: How bacteria can deal with spontaneous and environmental damage to proteins. Mol. Microbiol. 16: 835-845.

Watarai, M., T. Tobe, M. Yoshikawa, and C. Sasakawa. 1995. Disulfide oxidoreductase activity of Shigella flexneri is required for release of Ipa proteins and invasion of epithelial cells. Proc. Nat1. Acad. Sci. 92: 4927-4931.

Wulfing, C. and A. Pluckthun. 1994. Protein folding in the periplasm of Escherichia coli. Mol. Microbiol. 12: 685-692.

Wulfing, C., J. Lombardero, and A. Pluckthun. 1994. An Escherichia coli protein consisting of a domain homologous to FK506-binding proteins (FKBP) and a new metal binding motif. J. Biol. Chem. 269: 2895-2901. 


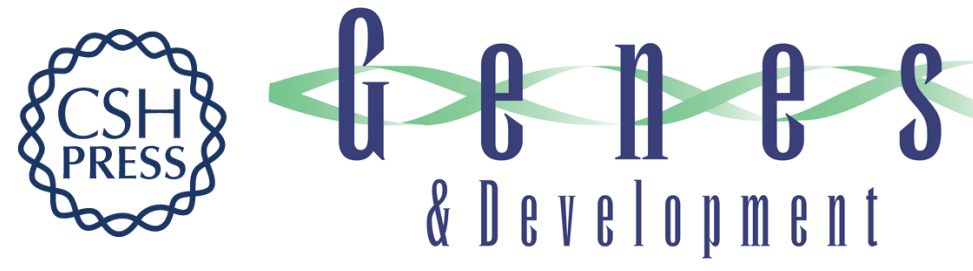

\section{Regulation of Escherichia coli cell envelope proteins involved in protein folding and degradation by the Cpx two-component system.}

J Pogliano, A S Lynch, D Belin, et al.

Genes Dev. 1997, 11:

Access the most recent version at doi:10.1101/gad.11.9.1169

References This article cites 64 articles, 32 of which can be accessed free at:

http://genesdev.cshlp.org/content/11/9/1169.full.html\#ref-list-1

License

Email Alerting

Service

Receive free email alerts when new articles cite this article - sign up in the box at the top right corner of the article or click here.

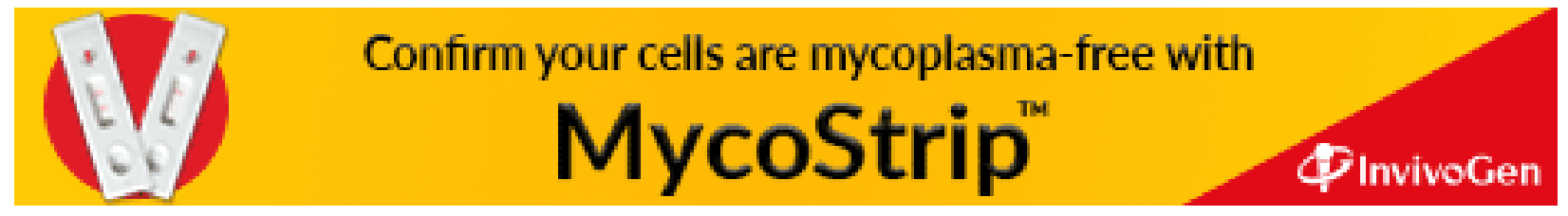

